\title{
AÇİ PADİŞAHI SULTAN ALÂEDDİN'İN KANUNÎ SULTAN SÜLEYMAN'A MEKTUBU
}

\author{
RAZAULHAK ŞAH
}

Vasco da Gama'nı 1498 senesinde yeni bir Hint yolu keşfettiği günden beri Portekizliler Hind sularmda kesif bir faaliyete girişmişlerdi. Önce yalnız ticaret maksadiyle bu tarafa gelen Portekizliler, sonraları yerlileri bazen tehdit ile, bazen de kandırarak bu bölgede sömürge sisteminin temelini atmışlardı. Portekizliler karşılarında en büyük düşman olarak o bölgenin Müslümanlarını görüyor ve her vesileyle onları zarara uğratmaya çalışıyorlardı. Zira bu bölgelerin ticareti eskiden beri Müslümanların elinde bulunuyordu. O suralarda devletler arası münasebetlerde din, birinci derecede ehemmiyet taşımakta idi. Bilhassa Hurıstiyanlarla Müslümanlar arasında vukubulan Haçlı seferlerinin acı hâtıraları henüz unutulamamıştı. Buna inzimâm eden ticarî rekabet, Portekizlilerle Müslümanlar arasında devamlı bir mücadeleye yol açtı.

Portekizliler yavaş yavaş yerleşerek o bölgede daha kuvvetli bir mevki işgal etmeye başladılar. Fakat o taraftaki bazı hükümdarlar Portekizlilere karşı koyarak onları bu bölgeden atmak istiyorlardı. Bu hükümdarlardan birisi de Somatra adası üzerinde Açi adını taşıyan memleketin Müslüman padişahı Sultan Alâeddin idi. Kendisi uzun zamandan beri Portekizlilerle savaşmakta idi. Fakat o taraftaki yerlilerin hemen hepsi Portekizlilerden yana oldukları için tek başına savaşmak zorunda kalmış ve bu yüzden zayıf düşmüştü. Nihayet tek başına Portekizliler gibi kuvvetli bir düşmana karşı koyamıyacağını anlıyarak dışardan yardım aramak zorunda kalmıştı. $O$ zamanlar o bölgelerde Portekizlilere karşı koyabilecek kudrette hiç bir devlet yoktu. Fakat bir süre önce aynı duruma düşmüş olan Hindistan'ın batı kıyısındaki Gücerat memleketinin hükumdarının Osmanlılardan yardım taleb etmiş olduğunu biliyordu. Gücerat hakimi Bahadur Şah Portekizlilere karşı Kânunî Sultan Süleyman'dan yardım istemişti ve o da 1538 de Hadım Süleyman Paşa'yı bir donanma ile o taraflara göndermişti. İşte bu vaka, Açi sultanı için bir örnek ve ümit kaynağı oluyordu. 
Gerçekten de o zamanlarda Osmanlı İmparatorluğu, Müslüman devletlerin en kuvvetlisi idi. XVI. yüzyılda doğudaki Müslümanlar, Osmanlıları, İslâm âleminin tek lideri ve gerçek koruyucusu olarak kabul ediyorlardı. Osmanlı hükümdarları da Halifetü'l Müslimîn ve Hâdimü'l-Haremeyn-i Şerifeyn olarak Müslümanları himâye etmek politikasını güdüyorlardı. 0 bölgedeki Müslümanlar her hangi bir yabancı tehlike karşısında gözlerini Osmanlılara çeviriyorlardı. Araştırmalarımız esnasında bu hususla ilgili olarak Topkapı Sarayı Müzesi Arşivinde Portekizlilerin zülümlerine karşı Osmanlılardan yardım isteyen Sultan Alâeddin'in 7-1-1566 tarihli bir mektubunu bulduk $^{1}$. Bu mektupta Açi Sultanı, Kanunî Sultan Süleyman'a büyük bir saygı göstermekte, Kuran ve Hadislerden örneklerle Müslümanların kâfirlere karşı birbirine yardımcı olmalarının farz olduğunu belirterek ilgisini kazanmaya çalışmaktadır. Aynı zamanda o taraflarda Osmanlı padişahlarının nüfûz ve itibarı belirtilmekte, daha önce Osmanlılardan gelen yardımdan bahisedilmekte ve o tarafların ahvali geniş bir şekilde tasvir olunmaktadır. Şimdiye kadar tanınmayan bu mektubu, mühtevasının önemine binâen bir tahlil, gerekli açılamalar ve Osmanlıların cevabı, ayrıca da aynı mesele ile ilgili diğer vesikalar ile birlikte aşağıda veriyoruz:

Biz bu bölgede Portekizlilerle savaşıyoruz. Çok sıkışık duruma düştük. Dinimizin de emrettiği şekilde "bu fakir miskin ve yetim ve düşman arasında müfred ve yalnız kalmış bendelerine rahmet ve şefkat idüp Allah için gaza yolunda...." bize yardım edin. Portekizliler ve Hindistan'daki bağlaşıkları sizinle mektuplaştığımızı öğrendikleri için bize saldırmalarından korkuyoruz. Allah ve peygamber aşkına bize ve Mekke'ye giden hacılara Portekizliler gelmeden yardım edin. Bundan önce size Ömer ve Hüseyin adl adamlarımızı göndermiştik ${ }^{2}$. 0 zaman Portekizlilerle müttefik olan padişahlar haber alıp Portekiz kuralına elçi göndermişler. Elçiler kurala "Açi padişahı Rum padişahından yardım istemiş siz de bize yardım edin" demişler.

1-Bak ek No. 1,2,3.

2 - Hammer 1547 de Portekizlilere karşı yardım istemek için Alâeddin'den bir elçinin Istanbul'a geldiğini kaydetmektedir. Bak Hammer, Osmanlı Tarihi (-Ata Bey tecümesi) VI., s. 6-7. Belki bu rica kabul edilmiştir çünkü aynı yıl Açı ve Portekizliler arasında vuku bulunan savaş hakkında Danvers şöyle diyor, "1547 de Portekizlilerin amansız düşmanı Açi padişahı Malakka'ya saldırmak üzere altmış gemiden müteşekkil bir donanma ile beş bin kişilik bir kuvvet gönderdi. Bu kuvvetin en iyi alayı, bir Müslüman kumandasındaki Türk ve Yeniçerilerinden müteşekkil idi" Büyük bir ihtimalla Danvers'in bahisettiği Türk kuvvetleri bu rica üzerine gönderilmiştir. Danvers, The Portugues in India, Being a History of the Rise and Decline of Their Eastern Empire, London, 1894. 1, s. 480-481.

3 - Açi padişahına karşı Portekiz yardımı alan hükümdarlardan en önemlisi Baas padişahı idi ki o eskiden beri bu yardımı alarak Açi padişahı ile savaşmakta idi. Danvers, aynı eser. 1. s. $438-447$. 
Fakat biz sizin her türlü yardımı edeceğinize güveniyoruz. Memleketimiz ile Mekke arasında Divâ denilen yirmi dört bin ada vardır. Bu adalar freng Kuvehsi (كووروسى) ${ }^{1}$ ile Zülümat deryaları arasındadır. Bu adalardan oniki bini meskûn ve oniki bini ise boştur. Bu adalarda yașiyan kimseler Şâfiî mezhebinden olup oruc tutar, namaz kllar ve hutbelerde isminizi zikrederler. Bunlar kumbar ipi satmakla geçinen fakir insanlarıdır. Bundan önce bu cezirelerin padişahı kâfirlerle çok çetin suretle savaştığı için onlar bu cezirelere giremezlerdi. Bu yüzden $970 \mathrm{H}$. (1562-63) yılında birçok istilalara uğradı ve zayıfladı. Neticede Padișah, ailesi ile birlikte Mekke'ye kaçarken furtınadan dolayı Muha'ya, oradan da Aden'e gitmeye mecbur oldu. Bunun üzerine Portekizliler adaları ele geçirip fakir halkı yılda yirmi dört bin kantar kumbar ipi vermeye mecbur ettiler. Bu adalar birbirine çok yakın olup, aralarından geçmek için yalnız dört yerde geçit vardır. Portekizliler bu yolları tutup oradan geçen hacı ve tüccar gemilerini esir alırlar. Esir edilmiyenleri ise top ateşi ile batırırlar. 972 (1564-65) yılında adamlarınız bu tarafa gelip yardım ettikleri zaman ${ }^{2}$ onlar ile Gücerat vezirlerinden Cengiz Han'ın Samedi denmekle meşhur olan çok büyük bir gemiye kara biber, ibrişim, darçin, karanfil, kâfûr, hisâlbend ve bu bölgenin diğer kıymetli ürünlerini Mekke cânibine gönderdik. Adı geçen adalara geldiklerinde üç galyon ve yedi kadırga Portekiz gemisi ile dört gün dört gece savaştılar. Portekizliler uzaktan ateş açarak gemide bulunan beşyüz Müslümanı esir aldılar ve gemiyi de batırdılar. ${ }^{3}$ Açi'ye deniz yolu ile sekiz günlük mesafede Seylan isimli bir vilayet vardır. Seylan'da “cevâhir ma'âdenleri olup gecelerde cevâhir nuru ile evleri rûşen olup çerağ (ışı) yandırmaya ihtiyacları yoktur". Oranın padişahı kâfirdir fakat halkın bir kısmı Müslümandır. Orada bulunan ondört camide sizin nâmınıza hutbe okunur. Kalikut'un pađişahı Sâmırî demekle meşhurdur ve ora halkınm çoğu Müslümandır. Orada bulunan yirmi beş camide de sizin isminize hutbe okunur. $\mathrm{Bu}$ iki padişahın vilayetleri birbirine çok yakın olup kendileri de Portekizlilerle savaş halındadırlar. ${ }^{4}$ Adam-

\footnotetext{
1 - Hindistan'da Portekizlilerin en önemli merkezi olan Goa kasdedilmektedir.

2- 6 numarah Mühimme defterinin 201. sahifesinde bulunan ve Mısır Beylerbeyine gönderilen 26 Recep 972 tarihli hükümden, Portekizlilere karşı savaşmak için donanma gönderileceği kararlaştırıldığı anlaşılmaktadır. Belkide bu adamlar bununla ilgili olarak gönderilmişlerdir.

3- Tarih Al-Şihrî̀ye göre beş Portekiz gurab ve galyonec Açi'den gelen Açililer ve Türk tüccarlarla dolu büyük bir gemiye saldırıldılar. Arahısız üç gün devam eden savaşta aşağı yukarı bütün Müslümanları öldürdüler. Canların kurtarabilen yirmi Müslüman Aden'e, birisi de Ahver'e geldi. Inglizcesi Serjeant R.B., The Portuges of the South Arabian Coast, s. 110, Oxford, 1963.

4 - Seydi Ali Reis Hindistan'a gittiği zaman Sâmer̂̂’nın adamları kendisini ziyaret ederek onun Osmanlı padişahına muti' olduğunu ve uzun zamandan beri Portekizlilerle savaşmakta olduğunu söylediler. Seydi Ali Reis, Miratülmemahk, s. 27.
} 
larınızdan Lütfi Bey bu tarafa ${ }^{1}$ geldiğinde Seylan ve Kalikut padişahları bize elçi gönderip padişah hazretlerine arz-ı ubudiyet üzere olduklarını söyleyip donanma-i hümayun bu taraflara geldiği zaman, halkları ile birlikte Müslüman olacaklarını bildirdiler. İnşaallah yüce himmetiniz ile doğudan batıya kadar mevcut olan bütün kâfirler ortadan kaldırılır ve şimdiye kadar hep kâfirlerin eline geçen sayısız cevahir, altın ve gümüş bundan böyle sizin asker ve mücahidlerinize nasip olacaktır. Mısır ve Yemen Beylerbeyilerine veya Cidde ve Aden Beylerine đüşmanlarınız değil kullarınız olduğumuzu haber verin. Lütfedip fakir, miskin, zayiflere silâh ve askerlerle yardım edin. Âlet ve techizatla mürettep donanma-i hümayun gönderirseniz bu taraftaki Portekizlilerin mahvolacağını biz taahhüt ederiz. Yardım etmezseniz mahvoluruz ve hacılarm yolu da Portekizliler tarafından kesilmiş olduğu için Müslümanlara büyük zarar olur. Bu taraftaki ve Hindistan'daki padişahlar Portekizlilerin yardımın arzu etmekte, fakat bizim dileğimiz yalnız sizden yardım rica etmektir. Lütfen baclışke, havâî toplardan kale dövecek toplar gönderiniz. Mısır ve Yemen Beylerbeyilerine ve Aden ve Cidde Beylerine emir verin ki adamlarımız o taraflara geldiklerinde bekletmeden yüce makamınıza çıarsınlar. Açi sizin köylerinizden biridir ve ben de hizmetkârlarmzdan birisiyim. Gücerat'ın eski valilerinden Karamanoğlu Abdurrahman yarar bir adamdur. Lütfi Bey'i bu tarafa gönderdiğinizde, Cidde'ye geldiği zaman gemi bulamayıp perişân oldu. 0 zaman Abdurrahman emrinize hürmet gösterip kendi cebinden bol para harciyarak Lütfi Bey ve yanmdaki adamlarmı bir gemiye bindirip bu tarafa gönderdi. Kendisi çok iyi bir adamdır; ona Cidde sancağını veriniz. Biz Lütfi Bey ve arkadaşlarından çok memnun kaldığımız için onların tekrar bu tarafa gönderilmesini rıca ederiz. Zira vilâyetimizin ve Hindistan'ın ahvalini görerek ve işiterek vâkıf olmuş kimseleridir. Bu tarafa göndereceğiniz adamlara tenbih edin ki buraya geldiklerinde bize itaat etsinler. İhsan ettiğiniz topçular selâmetle bu tarafa gelmişlerdir ve onların yeri yanımızda çok yüksektir2. Eğitim görmüş birkaç at ve hisar ve kadırga yapıcıları gönderilmesi rica olunur.

1 - II. Selim'in cevabî mektubunda da Lütfi Bey'in Açi'ye gönderildiği teyid edilmektedir.

2 - Mektuptan da anlaş̧hyor ki Osmanlıların Açi’ya gönderilen yardım yeni bir olay değildır. Ayrıca Tarih-i Açi'nin ifadesine göre Portekizlilerin adayı istila yolları arama emelleri beslemesi üzerine Kanunî Sultan Süleyman, kapudan Cağalazade Sinan Paşa emrindeki donanmayı Umman denizinden, ta uzak şarklara kadar gönderip Açi emirini himaye altına aldı. Hatta Açi padişahına bir de, üzerine mukaddes kelimeler yazılmış Sancak-i Âlî hediye etmişstir. Tarih-i Açi, Mehmed Ziya, Kostantiniye 1317, s. 81; Katip Çelebi de Açe'lilerin Osmanllardan yardım aldıklarını yazmaktadır, Cihannüma, Istanbul, 1945, s. 145. 


\section{OSMANLILARIN CEVABI ${ }^{1}$}

İstanbul'dan Açi'ye gönderilen mektupta da belirtildiği gibi Açi padişahınm elçisi Osmanlı başkentine varınca mektubun alıcısı Kanunî Sultan Süleyman vefat etmiş ve yerine II. Selim padişah olmuştu. II. Selim'in Açi padişahı Alâeddin'e gönderdiği 20-9-1567 tarihli cevabî mektupta, adı geçen padişahın dilekleri ve o taraftaki ahvâl hülasa edildikten sonra bu istekleri yerine getirmenin Osmanlı padişahı için hem dinî hem de ananevî bir görev olduğu belirtilmektedir. Osmanlıların Müslüman ülkeleri himaye altına almak ve onları kâfirlerden kurtarma politikasına ışı tutan bu mektubun muhtevası şöyledir:

Büyük padişahların ricalarmı kabul etmeyi âdet edindiğimiz ve din emirlerini yerine getirmek için, Süveyș'ten on beş kadırga ve iki barçe, hâssa topçulardan bir topçubaşı ve emrindeki yedi topçu, Mısır'dan yeteri kadar asker ve kale dövecek top, tüfek ve harp levazımatı gönderilmesi için emir verilmiştir. Bu donanmanın başında da en kıymetli kapudanlarımızdan Kurdoğlu tayin edilip bu taraftan gönderilecek adamlara size itaat etmek için kesin emir verilmiştir. Bu kuvvetin küçüğü büyüğü herkes emirlerinizi yerine getirecektir. Emrinize muhalefet edenleri Hızır Reis vasitasiyle cezalandırı. ${ }^{2}$ Gönderilen askerlerin bir yıllık maaşı kendilerine ödenmiştir. Siz de kâfirlerle savaşarak Müslümanların rahatça yaşamaları ve işlerini görebilmeleri için üzerlerinden düşmanların kötülüğünü kaldırmak yolunda bütün gayretinizi sarfedin. İşleri bittikten sonra topçulara dönmek için müsade edin ve oradaki olayları Mustafa Çavuş vasitasiyle bildiriniz. Geri kalan asker hakkında verilecek emirlerime göre hareket ediniz. Mektubunuz geldiğinde babam Sultan Süleyman Han "Melûn" Nemçe kuralının memleketinde bulunan Sigetvar kalesini muhasara edip "küffar-ı haksar-1 hezimet âsâr" ile savaşmakta idi. Kalenin fethinden sonra kendisi vefat etti ve vazifelerini ben üzerime aldım. Kâfirlerle cihad etmeye kesinlikle karar vermişim. O tarafta müstevli olan din düşmanlarım hakkından gelmek ve onları ortadan kaldırmak için size her zaman asker göndereceğiz. Siz o tarafta olup bitenleri âdetiniz olduğu gibi bütün ayrıntıları ile bize bildiriniz.

Yukardaki mektublardan anlaşılıyor ki Açi padişahı Osmanlılara çok güvendiğinden onlara yardım için baş vurmuş ve Osmanlılar da hị̧ çekinmeden yardım etmeğe hazır olduklarını bildirmişlerdir. İstanbul'dan gön-

1 Bak ek No. 4,5,6,7.

2 Bu husus Kurtoğlu Hızır Reis'e verilen Nişan-ı Hümayununda da açıkça belirtilmiştir. 
derilen cevapta Osmanlı padişahının yardım etmekte çok istekli olduğu ve bunun için bütün imkânlarını kullanmaya kararlı bulunduğu apaçıtır. Sultan Selim sözle kalmayıp Açi padişahına gerekli yardımı yapmak ve dileklerini yerine getirmek için hemen teşebbüse geçerek ilgililere fermanlar gönderdi.

Bunların ilki, yardım gayesi ile Açi'ye gönderilecek donanmanın komutanlığına atanmasına dair Kurdoğlu Hızır Reis'e gönderilen Nişan-i Hümayun'dur. ${ }^{1}$ Bu hüküm özetle şöyledir: Açi padişahı Sultan Alâeddin, elçisi ile mektup gönderip Portekizlilere karşı askerî yardım istemiştir. Kendisine Süveyş'ten on beş pare Kadırga, iki barçe vesair levazımat verilmesini emredip oraya giden donanmaya seni kumandan tayin ettim. Gönderilecek gemi ve askerle oraya varınca her hususta Açi padişahınm emrine göre hareket et. Buradan gönderilenlerden küȩüğü büyüğü herkes Açi padişahına itaat etsin. Onun sözünü dinlemiyenlere de hakettikleri cezayı ver ki başkalarına ders olsun.

Yemen Beylerbeyine gönderilen fermanda, ${ }^{2}$ Açi elçisinin geri gönderildiği bildirilerek kendisinin at, âlet ve bakır almak istediğinde hiç bir güçlük çıkarılmaması, alınan esbabın hị kimse tarafından karıştırılmaması emredilerek her türlü yardımın yapılması istenilmektedir. Bu hükmün birer sureti Aden ve Cidde Beylerine de gönderilmiştir.

Açi padişahınm "hisar ve kadırga yapıcılar" hakkındaki dileğini yerine getirmek için Mısır Beylerbeyine gönderilen hükmün ${ }^{3}$ özeti şöyledir: Açi padişahının elçisinin isteği üzerine dülger, demirci, kalkancı v.s. sanatçiler defter edilip sana gönderilmişlerdir. Oraya geldiğinde bu sanatçları hemen Açi padişahı elçisi ile gönderin.

Mısır Beylerbeyine gönderilen başka bir hüküm ${ }^{4}$ de Açi padişahına gönderilen kadırgalarla kendi isteği ile gitmek isteyen Mısır kullarına engel olunmayıp müsaade edilmesi hakkındadır.

Rodos Beyine gönderilen hükümde ${ }^{5}$ ise Açi padişahı elçisine dönmek için izin verilip kadırga ile Mısır'a gönderildiği ve Rodos'a vardığında “eğlendirmeyip" yanındaki kadırgaları ile sağ sağlam Mısır'a varabilmesi için kendisine refaket edilmesi emredilerek Mısır'a varınca da bindiği kadırganın İstanbul'a gönderilmesi istenmektedir.

\footnotetext{
1 Bak ek No. 8.

2 Bak ek No. 9.

3 Bak ek No. 9.

4 Bak ek No. 9.

5 Bak ek No. 9.
} 
Mekke Şerifi'ne gönderilen hükümde ${ }^{1}$ Açi padişahının elçisinin gönderildiği bildirilerek adamları ile o tarafa geldiğinde su, zahire ve kılavuz hususunda merkez hükûmetinden izin istemeden gereken yardımm yapılması, emin yoldan Mısır'a gönderilmesi ve elçinin at satın alması halinde hiç kìmsenin engel olunmaması emredilmektedir.

Yine Mısır Beylerbeyine verilen hükümde² de Açi padişahı elçisinin İskenderiye'ye vardığında iskelede ve diğer yerlerde hiç kimsenin kendisine, adamlarına ve eşyalarına karışmaması kesinlikle emredilmektedir.

Mısır Beylerbeyine ${ }^{3}$ ve kapudana ${ }^{4}$ gönderilen diğer iki hüküm de, Açi elçisi ile gidecek gemilere yararh adamların reis tayin edilmesi ve onlarm ücretinin de Osmanlı hükûmeti tarafından karşlanması hakkındadır.

Görüyoruz ki Osmanlılar Açi elçisine çok önem vermişlerdir ve memleketini Portekizlilerin tecavüzünden kurtarmaya kararlıdırlar. Fakat buna rağmen Açi seferi gerçekleşememiş ve o tarafa gönderilmek için hazırlatılan donanma Açi'ye gidememiştir. Bunun ilk sebebi de o sırada Yemen'de çıkan isyan olmuştur. Bunu da Açi padişahı elçisine verilen fermandan ve Açi padişahına gönderilen mektuplardan öğreniyoruz. Açi elçisine gönderilen 15-1-1568 tarihli fermanda ${ }^{5}$, Yemen'de isyan çıktığından dolayı yardım için gönderilecek donanmanın bu sene tehir edildiği, fakat durum normale döndüğü zaman "zikr olunan donanma muâhede olduğu üzere müretteb ve mükemmel irsâl olunur". şeklinde va'dda bulunulmaktadır. Osmanlı padişahı tarafından Açi padişahına gönderilen mektup da bunu teyid etmektedir. Bu cevabî mektubun yazılı̧ tarihi belli olmamakla beraber mühtevâsından 1569 sıralarında II. Selim tarafından gönderildiği anlaşılmaktadır. Bu mektuptan, Açi padişahının Sultan Selim'e tekrar elçi ve mektup gönderdiği de ortaya çıkyor. Zira kendisi 1567 de Portekizlilerle yaptığı bir savaşta büyük kayıplara uğramıştı. ${ }^{6}$

Bu mektubun ${ }^{7}$ meâli şöyledir: Adamınız vasıtasiyle mektup ve hediyelerinizi aldık. Mektubunuzda yardım istemişsiniz. Biz padişahların ricalañ-

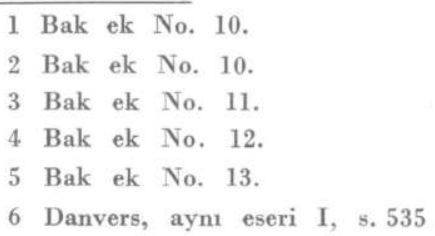

7 Feridun Bey münşeati C. II, s. 554; Sûret-i Mekâtib-i Hülefâ ve Selâtîn'da da bunun Sultan Selim tarafından gönderildiği başhkta açıkça belirtilmiştir. Topkapı Sarayı Müzesi Kütüphanesi No. R- 1959. s. $816_{b}-817_{b}$ 
nı kabul etmeyi âdet edinmişizdir. Nitekim bundan önce de kâfirlere karşı yardım istediğinizde de hemen teşebbüse geçtik. Fakat istediğiniz malzeme gönderilecekken ânîden Yemen'de isyan çıktı. Oraya asker gönderilmesi lazım olduğundan sizin isteklerinizi yerine getirilmekde gecikti. $O$ taraftaki düşmanlarm haklarından gelmek için gönderilen kuvvetlerin dönüşünde asker ve donanma gönderilmesi için kesin karar verilmiştir.

Fakat Osmanlıların bir işi bitirmeden öbürüne başlamamak âdeti, gerçekten Portekizliler tarafından çok sıkışık duruma sokulan Alâeddin'e yardım etmelerine fursat vermedi. Portekizliler Açi padişahını hiȩ rahat bırakmıyorlardı. 1570 de Portekiz kaptanı Luiz de Melle, on dört gemi ile Açi limanında bulunan ve Açi veliahdinin kumandasındaki altııs gemilik donanmaya saldırdı. Bu saldırı sırasında prens de dahil olmak üzere 1200 Açili öldürüldü. Üç tekne ve dört gemi ele geçirildi. Geri kalanlardan biri hâric, bütün gemiler batırldı. ${ }^{1}$ Kâtip Celebi'nin "Menlevis" dediği Portekiz denizcisi; Danvers'in Melle de Luiz diye zikrettiği Portekiz kaptanı ile aynı şahısdır. Metinlerde görüldüğ̈̈ tarih ve gemi sayılarındaki fark ise kaynakların ayrı ayrı olmasından ileri gelmektedir. ${ }^{2}$ Osmanlılar Kıbrıs ve Tunus işleriyle meşgul olduklarından Açi'ye gönderilmesi kararlaştırılan donanmayı o tarafa gönderemediler. Bunu da Osmanlılar tarafından Açi’ye gönderilen başka bir mektuptan öğreniyoruz. Bunun hangi tarihte ve hangi padişahın zamanında kaleme alındığı mektubta belirtilmemektedir. Fakat içinde zikredilen vakalardan anlaşıllyor ki bu mektup II. Selim zamanında ve 1571 tarihinde yazılmıştır. Açi padişahının yardım isteğile gönderdiği üçüncü mektubuna cevap olarak gönderilen bu mektupta yardımın gecikmesinin Yemen isyanı, Kıbrıs ve Tunus seferleri yüzünden olduğu belirtilerek, Kıbrıs ve Tunus'un fethedildiği haber verilmekte, Açi padişahının dilekleri yerine getirilmek için kesin karar verildiği bildirilmektedir. Mektup özetle şöyledir:

Elçileriniz Sünbül Ağa ve Hamza mektubunuzu getirdiler ve ricalarmızı bize ilettiler. Bundan önce de din emirleri gereğince ricalarını kabul e-

1 Danvers, aym eser, I. s. 557.

2 Cihannüma. s. 145. İstanbul, 1945. Cihannüma'daki metin şöyledir: “....... cezire halkının dinleri mühtelefdir. Sevâhil-i bahr sükkânî ehl-i İslamdır. Ortalarında abd-ı esnâm olur ve bunların cümlesi cenkçi olup Muhammedîlere mesmûm ok ve yay kullanurlar ve kumbara isti'mâl ederler lakin ahalisi ve gayrı Türk'ten ceng sanatını ögrendiler. Zira ol semte Portakal müstevli olmağla onlardan istimdad edip getirirdiler ve nice kere mağlup oldular. Portakal cengleri arasında bu galebe meşhurdur ki miladın 1579 senesinde Menlevis nâm Portakal on iki gemi ile bu cezire halkının yüz kadar kadırgasın bozdu", 
dilerek istediğiniz malzeme, âlet vesâire gönderilmesi için emir verilmiști. Fakat bunlar gönderilmek üzere iken ânîden Yemen'de isyancılar başkaldırdılar. O taraftaki halkı ve vilayeti doğru yoldan sapanların kötülüğünden kurtarmak lazım olduğu için bir miktar asker oraya gönderilmişti. Daha sonra denizyolu ile hacca giden Müslümanların yollarında bulunan ve onlara zarar verici niteliğini taşıyan kâfirlerin elindeki Kıbrıs ceziresini de kâfirlerden temizlemek en mühim vazife olduğu için bir miktar asker de oraya gönderilmişti. Bu sebeple ricalarınız yerine getirilemedi. Büyük savaştan sonra Kıbrıs, kâfirlerden temizlenip Osmanlı topraklarına dâhil edilmiştir. Öte yandan Cezâyir-ı Garb Beylerbeyisi Ali Paşa, Tunus hakimi ile savaşarak orasını da fethetmiştir. Yemen'e gönderilen askerleri de düşmanların haklarından gelip galip gelmişlerdir. O taraflardaki durum normala döndükten ve askerlerin geri dönüșünden sonra dilekleriniz yerine getirilecektir. Buna kesinlikle karar verilmiştir. Bu mektubun metinini de makalenin sonuna koyuyoruz ${ }^{1}$.

Yemen'deki isyan 1570 senesi sonlarına doğru bastırılmışsa da durumun normale dönmesi biraz daha uzun sürmüştür. Gerçi Ali Paşa, Kıbrıs fethi esnasında, Tunus'u da ele geçirmiş fakat civardaki yerlerin fethi ve Osmanlıları̣ oralara yerleşmesi 1574 e kadar sürmüştür. Bu yüzden Osmanlıların vadettikleri yardım da gerçekleştirilememiştir. Diğer taraftan Sultan Alâeddin'in ölmesi ve 1574 de de deniz seferlerine pek önem vermiyen Sultan III. Murad'm tahta geçmesi, tasarlanan seferin yapılmamasına âmil olmuştur.

\section{AÇI PADİŞAHI ALÂUDDİN'İN KANUNI SULTAN SÜLEYMAN'A GÖNDERDIĞİ MEKTUBUN METNİ (TOPKAPI SARAY ARŞİİ NO. E-8009)}

$$
\begin{aligned}
& \text { أن اولى ماينسخ به اسباب الهجر و العباد و ازكى مايتاع كذبه انواع العبودية } \\
& \text { و الوداد اهداء خدمات تنشعب من خالص طوية الله شاهل ها ودعوت زتزفع } \\
& \text { الى سبع السموات الملايكة مصاعدها تختص للمضرت الخنكار الاعدل الافخم } \\
& \text { وكرم الابجد من هوالشهس السلطنة و الدولة و الملىى تتآلم من مربأسها الكغرة } \\
& \text { و العلى و قور الخلافة في دين الته المالكك الديان يذهب ظلمهت الكفر عن وجوه } \\
& \text { هذ الزمان خغقت فن الملوك اعلام افضاله و احسانه و نطقت محتع الانس بمحامده }
\end{aligned}
$$

1 Sûret-i Mekâtib-i Hûlefâ ve Selâtin s. $881_{\mathrm{a}}-883_{\mathrm{a}}$ Bak ek No. $14,15,16$ 


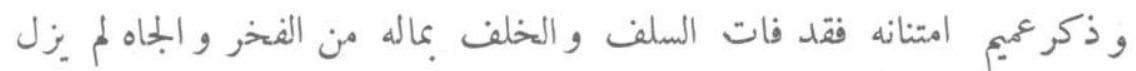

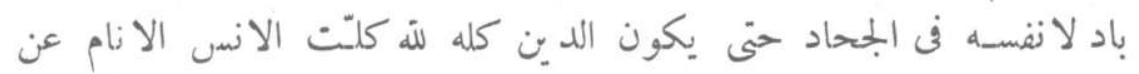

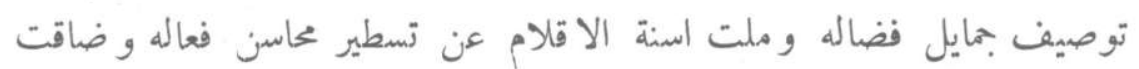

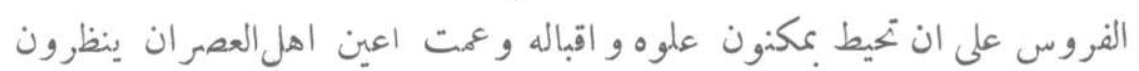

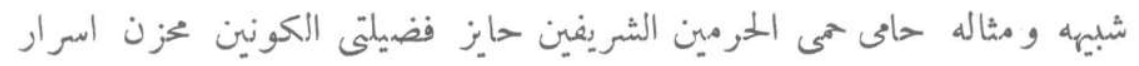

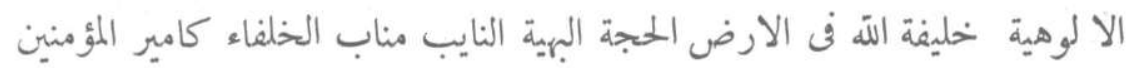

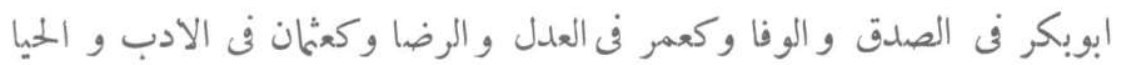

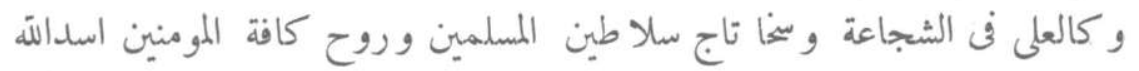

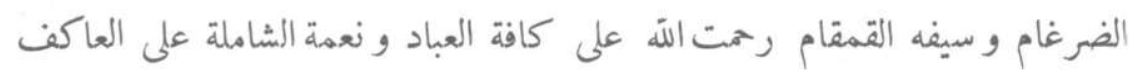

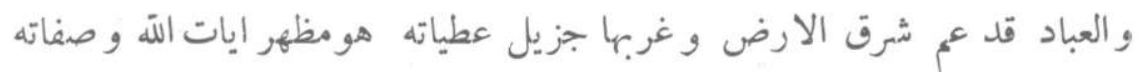

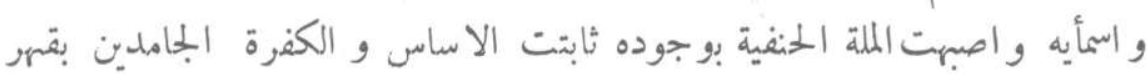
سلطنة متزلزلت الاعضاء و الانفاس وهوخيار عبادالته في زمانه صواعق الملت الماند

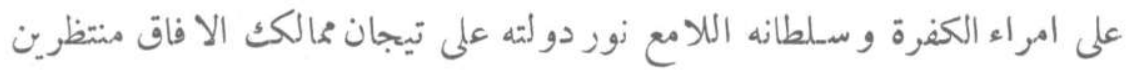

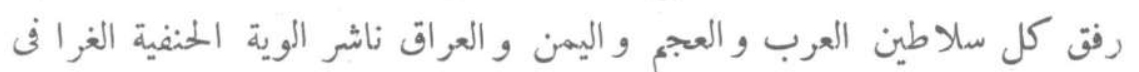

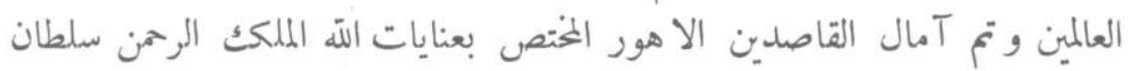

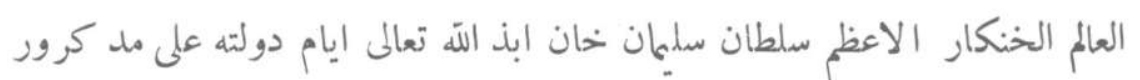

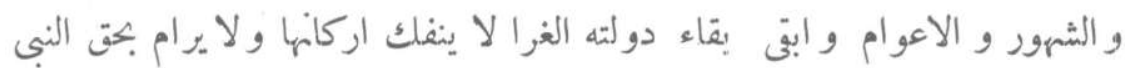
و اله و اصحاب الكرام فو الله العظيم ومحمد صلى الته عليه وسلم النبى الكريع

ki Padișa-1 âlem-penâh zıll-ı ilâh hazretlerinin dergâh-1 a'lâ ve bârgâh-1 muallâlarından özge mesnedimiz ve melceimiz ve mahall-i şikâyetimiz olmayub zâhiren ve bâtınen i'tikadımız müteyekkindir ki eger şimdi değin bu bendelerinin keyfiyyet-i ahvalinden ve işbu diyarda ve Tahterrih'de küffar-1 hâksar ile alâ meddi'ş-şuhûr ve'l-eyyâm cihâd-ı fi sebil'l-lâh olduğu hususda ol dergâh-ı muallâya zâhir ve bâhir olaydı terahhum ve şefkat-ı şâhâneleri 
hâil-i hâl-ı nâ-muradân olup murâdât ve maksudâtımız bi'l-külliyye hedef-i icâbete maekrûn. olunurdu. Alelhusus selâtin-i adl-âyîn üzerine vacibdir ki din-i hakka takviyet idüp iânet buyuralar. Nice ki Kurân-1 mecidde vâriddir

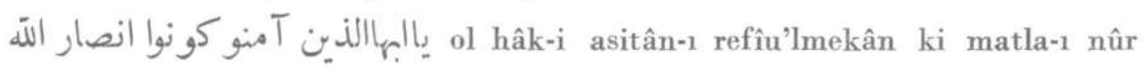
u ihsân ve şâmil-i hâl-i bendegândır rica olunur ki bu fakir ve miskin ve yetim ve düșman arasında müfred ve yalnız kalmış bendelerine rahm-u şefkat idüb be-resme'l, gaza-i fî sebîl'l-lah ve tedmîrü'l-kefereti'l-müşrikîn a'dâü'd-dîn hasbeten lillâh ve resulihi asâkir-i mansûre ve âlât-1 cihad ve mesâlih-i harb bilüb görmüş müdebbir kullarından ihsân olmasına inâyet buyurula ve وما تفعلوا من خير تجيدون عند الله fe-emmâ delâil-i i'câzda ve ehâdis-i nebevide vârid olan fezâil-i gazv ve'l-iânet-i aliyye ol halifetü'l-lâhi fi'l-âlemîn hazretlerine rûşen ve mübeyyendir ve şimdiki halde küffâr-ı hâksârlarda ve temam vilâyet-i Hindustan kâfirlere muhib olan padişahlar da ol âsitan-ı a'lâ kubelinden bu bendelerine resâyil vusûl olduğu meşhûr ve mübeyyendir, ol ecilden sür'atle üzerlerine varmakdan havf ve hazer ederler. İmdi Allahın hürmeti hakkı içün olsun ve Muhammed Mustafa sallelâhu aleyhi vesellem hürmeti hakkı içün ve ecdâd-1-merhumîn ruhları hakkı içün olsun ki bu bende-i üftâdelerine ve bu diyarlarda olan ehl-i islâm ve hüccâc hallerine șefkat ve rahm buyurub iânet ve imdadları ahsen-i vechile ve esra'-i vaktile ihsân buyurula mübâdâ ki küffâr-1 hâksâr ve cümle eâdiyü'd-dîn ol dergâh-1 muallâdan imdad erişmeden ittifakla üzerimize gelip muharebe ile istikdâm edeler ve bundan akdem Ömer ve Hüseyyin kullarımız dergâh-i a'lâ kıbeline revâne olunduklarında cemî' Hindistan vilâyetlerinden küffâr-ı hâksârle müttefik olan padişahlara ilm olundu anlar dahi Portakal pađişahma elçi gönderüb ol küffâr-1 a'dâi'd-dîn ve fecere-i melâînden iânet istid'â idüb arz eylediler ki Açi padişahı istid'â ve iânet ve imdâd Rum padişahından eylemiştir, bizim dahi Portakal padişahından iltimasımız vardır görelim Açi padişahına Rum padişahından muradı hasıl olur veya bizim Portokol padişahından hâsıl olur. Lâkin i'tikadımız ذلك بان الته مولى الذين آمنو bizim itimadımız ve itikadımız Allahın fazlına ve padişah-1 âlem-penâh zull'l-lâh hazretlerinin tesaddukatlarına sâbit ve vâsıkdir ve padişah-ı zıll-i ilâh hazretlerinin tasaddukatlarından me'mulât ve mes'ulâtımız hâsıl olması mukarrerdir ve dahi dergâh-ı muallâya arz olunur ki bu diyarla Mekke-i Şerîfe şerrefehu'l-lâhu tealâ arasında Diva demekle ma'rûf yirmi dört bin ceziredir ol cezirelerin bir ucu Frenk Gûvahsına ve bir ucu Zülümât deryalarma ulaşmıştır ve ol yirmi-dört bin cezireden on iki bin ceziresi ademle meskûn ve on iki bin cezireleriharab 
gayr-1 meskûndur ve ol cezâyirin ahâlisi kâffeten Peygamber-i âhiri'zzaman sallellahu-aleyhi vesellem hazretlerinin ümmetlerinden Şâfiî mezheb-i din-i mübîn olduğu vech üzere namâz kılıcı ve oruç tutucu her cezirelerinde cami'ler bina idüb padişah-1 âlem-penâh zıll-i ilâh hazretlerinin mübarek ve âli ism-i şeriflerine hutbe okuyub izdiyâd-i ömru devlet-i rüz-efzûnlarma bi'lgüdv ve'l-âsâl Fâtiha-hân fukara ve zuafâ ve mesâkinlerdir ve kuvvet-i yevmiyyeleri balık olmakla ve kûr-i hindî yemekle ve nârcil ağacından hasıl olan lifden kumbar ipini büküp ol cezirelere uğrayan gemilere satmakla geçinir zuafâ ve mesâkînlerdir ve ol cezirelerin ekserilerinde anber-i hâm bulunur ve bundan akdem ol cezirelerin bir padişahı olup küffâr-1 hâksârle alâ meddü'd-dehr ve'l-asr husûmet ve muhârebe etmekle küffâr-ı hâksâr ol cezirelere dahl edemezlerdi. Şimdiki halde sene dokuzyüz yetmişinci tarihinde küffâr-1 melâîn-i a'dâi'd-dîn kesretle ol padişah üzerine gidip ve an zebûn eyleyüb padişah zaif-i hâl olmağla kendu ehl u iyâli ile azîmet idüb Mekke-i Şerife gider iken âhir-i mevsim olmakla Muha ve Aden cânibine çıkıp padişah-ı âlem-penâh hazretlerinin taht-i livâ-i adâletlerinde zelîl ve hazîn ve miskîn kalmıștır. El'ân ol cezireler kamusu küffâr-ı hâksârların hükmüne girip yıldan yıla değin ol fukarâ ve zuafâ ve mesâkînden yirmi dört bin kantar kumbar ipin gemilerine alât ve isti'dâd itmek içün zülmen ve cebren alırlar ve dahi cemî' Tahterrih iskelelerinden hacılar ve tâcirler gemileri Mekke-i Şerife şerrefehu'l-lâhu teala cânibine revâne olduklarında cezâyir-i mezkûrenin arasından geçerler ve cezâyir-i mezkûre dahi birbirinden bir ok iki ok atımı mikdarmca dûr olup yirmi dört bin cezire arasından hemen dört yerden gemi geçecek yol vardır bâki cezâyirler arasından gemi geçmeğe yol yoktur. Şimdi ol geçit olacak yerleri kâfirler bekledüp cemî' Tahterrih'den Mekke cânibine sefer eden tacirler ve hacılar gemileri ol geçit üzerine vardıklarmda kimini fursat bulup esir ederler ve her kimi ki fursatları olmayub ahz edemezler anı ırakdan top darbiyle batururlar. Ol gemide olan müslümanların kimileri deryada gark olup ve kimileri derya yüzünde devşirip esir ederler. Sene dokuz yüz yetmiş ikinci tarihinde Lutfi kulları bu cânibe gelip muâvedet ettiklerinde anlar ile Hindustan'm vilayet-i Gucerat vezirlerinden Çingiz Han gemilerinden صمدى demekle ma'rûf ve meşhur azîm ve büyük gemi bu diyardan on altı kantar fülfül ve ibrişim ve darçın ve karanfil ve kâfur ve hisalbend ve sâir Tahterrih metâ'larından yüklenip Mekke-i Şerife cânibine müteveccih olduklarında zikr olunan cezirelere vardıklarında ü pâre galyot ve yedi pâre kadırgaya sataşub dört gün ve dört gece küffâr-i hâksârlarla muhârebet eyleyub kâfirler ol gemi ahzına firsat bulamadıklarm- 
da rakdan top darbiyle batırıp ol geminin içinde beş yüz nefer müslüman kimileri deryada gark olurlar ve kimileri kâfirler su yüzünde devşirip esir eylediler. Ve dahi ol dergâh-ı muallâya arz olunur ki Seylan pađişahı bir kâfir padişahdır onun vilayetlerinde cevâhir ma'denleri olup gecelerde cevâhir nuru ile evleri rûşen olup çerâğ yandırmağa ihtiyacları yokdur. Ol vilâyet dahi bizim diyarımızdan derya yolundan sekiz günlük mesâfe olup ve ol diyarın ba'zı ahalileri ehl-i islâm din-i mübini üzere namâz kılıcılardır ve anın vilayetlerinde on dört yerde cami'ler bina idüp padişah-1 âlempenâh hazretlerinin mübarek ve âlî ism-i șeriflerine hutbe okuyup izdiyâd-ı ömru devletleri için Fatiha okurlar ve Kalikut padişahı dahi Sâmerî demekle ma'rûf ve meşhur bir kâfir padişahdır anın vilayetleri reâyası ekseri müslümanlardır ve anın vilayetinde dahi yirmi dört yerde cami'ler bina idüp anda dahi padişah-1 âlempenâh hazretlerinin mübarek ve âlî ism-i şeriflerine hutbe okuyup izdiyâd-ı ömru devletleri için Fatiha-i fâyiha okurlar işbu iki kâfir padişahları dahi vilayetleri birbirine yakındır anlar dahi küffar-ı hâksar ile meddü'd-dehr ve'l-asr muhârebet ve muhâsemet idüp küffar-ı haksâr anların vilayetlerine dahl edemezler. Çünki Lutfi kulları bu canibe vüsûl bulduklarm Seylan ve Kalikut padişahlarına haber olundukda anlar bu canibe elçiler gönderüb arz eylediler ki biz Padişah-1 âlem-penâh-1 zilli-ilâh hazretlerinin hizmetkârlarından olup ahd u misakları olundu kim inşallahü'l-aliyyi' 1-alâ Padişah-ı âlem-penâh hazretlerinin mübarek donanmay-1 hümâyûnları bu diyarlara ubûr bulduklarında kenduları imana gelip șehâdet getureler ve kendu vilayetlerinde olan küffâr reayâları dahi cemîan imana getirip din-i bâtıldan din-i hakka doğru yola giderler. İnşallahü-l-aliyyi Padişah-1 âlem-penâh hazretlerinin ulyâ himmetleriyle Maşrıkdan Mağriba değin cümle küffâr âsârları mahv olup İslâm dinine girerler ve dahi marûz olunur ki nice cevâhir ve altun ve gümüş maadinleri bî-hesab bulunur. Bunca zamandan beru küffâr-1 hâksârlara nasib olmuştu inşallahü'l-kadîr anlar dahi Padışah-ı âlem-penâh hazretlerinin asâkir-i mücahidîn ve guzzât-1 muvahhıdîn kullarına nasib ve kısmet olacaktır ve dahi ol dergâh-1 muallâya ricay-ı vâsıkımız oldur ki bu bendelerini sâir padışahlar a'dâdından saymayub kendu kullarından diyar-1 Mısr Beylerbeyisi veyahut Yemen Beylerbeyisi veya Cidde ve Aden Beyleri kulları a'dâdından Padışah-1 âlem-penâh-ı zıll-ı ilâh hazretlerinin etraf vilayetlerinde sadaka yiyen garib ve miskin ve hazin kulları a'dâdından ma'dûd buyuralar ve dahi ol dergâh-ı muallâdan istid'a olunur ki bizim ricamız ol dergâh-ı muallâdan kat' olmayıp bunca hacılara ve zuafâ ve mesâkine kâfirlerden olan hayf ve gadr hâtır-ı âtır-1 cihan-muhite takdir itdürüb rahm ve şefkat-ı Hüsrevâneleri bu fukaranın haline zuhûr 
bulup Padışah-ı âlem-penâh hazretlerinin gayet-i tasaddukatlarından beresmi'l-gazâ ve'l cihad-ı fî-sebili'l-lâh âlât-1 cihad ve esliha-i gazâ ve imمن اعانتك العاليه inâyet rica olunması babında ihsân buyuralar ان الته لايضيع اجر المحسنين Ve eger ol dergâh-1 muallâ ki melce-i zuafâ ve gurebâ ve mesned-i erbâb-1 hâcâtdır bu bende-i kemterînlerine rahm ve şefkat idüp donanmay-1 hümâyunları asâkir ve âlât ve yarak inâyet ve ihsan olunursa İnşallahü'l-kadîrülmuktedir din-i mübîn uğruna ve Allah yoluna gazâ idüb Padışah-ı âlempenâh hazretlerinin mübarek ve ulyâ himmetleri ile küffâr-1 hâksârların âsârlarm bu diyardan ve cemî' Tahterrih'den mahv etmeğe bu bendeleri zâmin ve kefildir. Şöyle ki ol dergâh-1 muallâdan bu bendelerinin muradâtı hasıl olmayub gaza-i fî-sebilillah uğruna asâkir ve âlât ve yarak inâyet olunmaz ise sonra bu bendelerinin haline ve cemî' Tahterrih'de olan ehl-i İslâm ve huccâca kâffeten teessüf olunmak mukarrerdir. Ve huccâc yolları kâfirlerden makfûl olub cemî̀' Müslimanlara hayf olacakter. Amma bizim ricamız Padışah-1 âlem-penâh zıllullah-ı fi'l-âlemîn hazretlerinin eltâf-ı âmmelerine vâsıkdır ve her kim ki ol dergâh-ı muallâya iltica etmiş ise ricası hâib olmamıştır bu diyarın ve Hindustan padışahları bilkülliyye Portukal'dan imdad ve iânet temennâ eylediler ve bizim murad ve gayet-i temennâmız ol dergâh-1 muallâdan râfi' ve mufavvez olmuştur zira ki kendu canımız ve cehdimiz ve malımız gaza-i fî-sebilillah yoluna koyub ümidimiz budur ki gazâ silâhları sâyesinde hadis-i Nebevî muktazasınca ki الجنة تحت ظلال السيوف mutezellil ve âsude-hâl olmaktır ve rûz-i kıyametde وم الوقو ف بين يدى وسلم

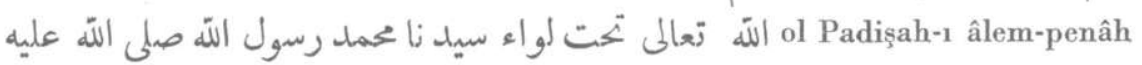
hazretlerinin taht-1 ikdâmlarında mücâhidîn zümrelerinde haşr olmak nasibimiz ola و هو المو فتق و المين Ve dahi ol dergâ-1 muallâdan rica olunur ki bacleşka ve havayî ve şâika toplardan hisâr dövmek için ihsân buyurula ve diyar-1 Misr Beylerbeyisi ve Yemen Beylerbeyisi ve Cidde ve Aden Beyleri kullarına ferman-1 cihan-mutâ'-1 vâcibü'l-inkıyâd ve'l-ittibâ' sâdır oluna ki her gâh bu cânibden dergâh-ı a'lâ kıbeline adamlarımız irsâl olunduklarında yollarda ta'vîk ve ta'tîl ettirmeyub esra' vechile dergâh-1 a'lâ kıbeline revâne oluna ve her mevsimde ol nevâhîden bu bendeleri içün at ve nuhas ve yarak alındıkda bu diyara getirmek hususuna mâni' olup te'hir olunmaya ki ol cevânibden dahi ahbâr-1 bekâ-1 devâm-1 devlet-i rûz-efzûnlarını işidüb mesrûru'l-hatır ve tayyibü'l-meâsir olmakdır. Zira ki vallâhilazîm işbu Açi dahi Padişah-1 âlem-penâh hazretlerinin köylerinden bir kỏydür, bu bendeleri dahi hidmetkârlarından bir hidmetkârım. Egerçi kemâl-i eltâfa gayetle 
kelâm-ı tavîl ile tasdî'-i evkat-ı șerifleri olundu ise lakin Lutfi kulları cemî’ ahvâlimize ve ef'âlimize ve gaza uğruna cedd u cehdimize padışah-ı âlempenâh hazretlerinin hidemât-i şeriflerine i'tikadımıza ve ihlâsımıza şâhid ve vâkıfdır ve dahi ma'rûz olunur ki ol cânib-i kamme-i kubbe-i Hıdra'dan كالن والسلوى و مايده 'Lutfi kulları bu diyara irsâl olundukda ahsen zamanda Hazret-i İsa gibi nâzil olub cânımıza canbahş ve ruhumuza râhet resân olmuştur. Yine ol mevsimde cemî hidemât ve mesâlihlerin her ne ise evvelâ ve âhurâ vech-i maksûd üzere görüp ve bizim ademlerimizle Rahmetü'l-yekîn demekle ma'rûf gemimize binüb üç gün ve ụ̧̈ gece nice bâzirgânlar gemileri ile sefer eylediklerinde gemileri sulanub ma'raz-1 helâke mütevecih olmuş iken hazret-i Rabbi'l-erbâb ve müsebbibü'l-esbâb eltâf-ı rahmetinden ve Muhammed Mustafa Salevatüllah vesellem aleyh a'tâf-ı kereminden ol demde Lutfi kullarına uyku hâil olup vâkıada görür kim ol Padısah-ı âlem-penâh zillüllah-1 fi'l-âlemîn hazretleri ol gemide bulunup Padışah-1 âlem-penâh hazretlerinin ferman-1 hümâyûnları Vezir-i a'zam hazretlerine olur kim bu gemiyi kendu âdemleriyle çıktığı yere râci' eyleyin. Ol demde Lutfi kulları uykudan uyanub kâdir-i kün fo yekûn kendu kemal-i kudretinden karşıانه على انلى ما يشاء قدئ işbu hâl dahi Padışah-ı âlem-penâh hazretlerinin kerâmât ve velâyâtlarındandır kim bunca gemiler arasından iki rüzgar peyda olup Lutfi kulları olduğu gemiye dönmek ruzgârm ihsan olundu ve bâzirgân gemilerine gitmek ruzgârı inâyet kılındı نحمدالله على نحماته Ve dahi sâbılka diyar-1 Gucerat vilayetleri vezirlerinden Karamanlığlu Abdurrahman kulları yarar ve kârgüzar ve sâir hidemâta sezâvâr bendeleridir ve Lutfi kulları i'tâb-1 aliyyeden bu diyara irsâl olundukda Cidde benderine geldiklerinde bu cânibe gelmek içün gemi bulmamağla hayran ve mütefekkir olduklarında zikr olunan Abdurrahman kulları Padışah-ı âlem-penâh hazretlerinin emr-i âliyelerine ta' zîm ve tekrîm idüb kendu malından bi-gayr-ı hisab harc eyleyub bir gemisini Lutfi kulları ve cemaatlarını bu cânibe ulaştırmağa irsâl eyledi ve dâimü' l-evkâtda Padıșah-1 âlem-penâh hazretlerinin hidemât-ı șeriflerinden taksirât eylemeyub cân u gönül ile hâdım-ı i'tâb-ı âliyelerdendir, öyle olsa ol dergâh-ı muallâdan rica olunur ki Abdurrahman bendelerine Cidde-i ma' mûre sancağın inâyet ve erzanî buyurulmasına inâyet buyurula. Bâki ferman Ulu'l-emre mufevvazdır. Ve dahi Lutfi kulları ve cemââtları ferman-ı hümâyûn müteallik olduğu vech üzere şolki kemâl-i emânet ve istikamet ve hüsn-i ihâle-i hidmet ve ubudiyyet getirmek hususunda bi-vus'il-tâkat ve'l kudret 
ve kadri'l-istitâati ve'l mekneti müra'ât-1 sülûk-i sebîl-i sedâd ve rıâyet-i tarik-i cedd u ecdâd idüb kemâ yelîk ve yenbağî meşhurü'l-mesâi vâki' olup ve bu diyarm ahalisini kâffeten müşârünileyh bendelerinin hüsn-i sîret ve ahlak-1 pesendîdeleri müstağrak-1 hadd-i kemâlde şükran gösterdikleri ile Padışah-1 âlem-penâh hazretlerinin her vechile mezkûrü'l-mefâhir ve meşhûrü'l-meâsir bendelerinden olmağın biz dahi kemâ hüve'l-maksûd razı ve hoşnûd olmuşuzdur. Öyle olsa âtıfet-i şâmile-i şahâne ve rahmet-i kâmile-i hüsrevâneleri cânibine dergâh-1 a'lâ kıbeline revâne olundu. Mereûdur ki inâyet-i âliyeleri ile manzûr ve himayât-i seniyyeleri ile mesrûr kılınıp dergâh-1 âlem-medârdan müyesserü'l-murâd ve mecburü'l-fuâd kllınması erzânî buyuralar ki istihkak-ı temâm ve liyâkat-1 mâlâ-kelâm ile mustahak ve lâyık bendeleridir inşallahü'l-aliyyi murâd olunur ki mezkûr bendelerini yine bu cânibe irsâl olunması babında inâyet buyurula, zira ki tamam vilayetimizin ahvâline ve sâir Hindustan diyarmm ahvâline kimini nazar ile görmek ile ve kimini hikâyâtdan işitmekle vâkıf ve mâhir olmuş bendeleridir ve dahi rica olunur ki bu cânibe irsâl olunan kullarına sipariş idüb ki bu diyara geldiklerinde bizim itaatımızda olup bize muhâlefet eylemeyeler ve sekiz nefer topçu ki ol dergâh-1 muallâdan bu bendelerine ihsân olundu idi cemîa sıhhat ve selâmet üzere bu cânibe vâsıl olup anların makamı bizim yanımızda cevâhir dağlarından azîm ve mu'teberdir ve ol dergâh-1 muallâdan birkaç aded at kâmilü't-ta'lim ve hisar ve kadırga yapıcılardan istid'a olunur, inâyet buyurula. Elân ol âsitane-i a'lâ kıbıline yüz sürmek için kendu kullarımız Hüseyin el Muhâtab berütbet peymâyî-1 ma'refe gönderildi. Lâ cerem ber mûcib-i ihyây-1 ulûm-1 kavânûn-i nasafet ve icrây-1 kavâid-i âyin-re'fet hurşid-i- tâbân-1 inâyetleri meşârık-1 izzet u iclâldan tâli' ola. Hemîşe kıyâm-1 hyyâm-1 saltanat ve devâm-1 memeleket pâyende bâd bi-rabbi'l-ibâd. Tahrîren fî evâsıt-1 şehr-i Cemâzi's-sâni sene selâse ve sebîn ve tisa mîe.

AÇİ PADIŞAHININ YUKARIDAKİ MEKTUBUNA OSMANLI PADİŞAHI II. SULTAN SELIM'IN GÖNDERDİĞI CEVABÎ MEKTUBUN METNI: ${ }^{1}$

Mühimme Defteri No. 7, s. 90-93, Sıra No. 244

Açi Padişahına yazılan nâme-i Hümâyûnun suretidir. Sernamesi merhum Koca Nişancı Beyin inşasıdır.

Vâlâ-cenâb, saltanat-meâb, hilâfet-intisab, rif'at-menâb, izzet-nisâb devlet-cenâb, saltanat-şlâr, ma'delet-âsâr, mâlik-i rikâbü'l-ümem, sâlik-i

1 Bak ek No. 4-5-6-7 
ekâdıl-himem, muğîsü'l-enâm, nâsıb-ı livâi'l-islâm, sâhib-i lutf ve'n-nevâl, melikü'l-hısâl, melikü'l-fiâl, râfi'-i elviyetü'l-ızz ve'l-celâl, min'es-semek-i ile-ssemâk nâsıb-1 râyâtü'l-adâlet alâ muhaddebi felekü'l-eflâk, el-fâyiz bi'l-bürci'lmuallâ min kıdâmi'ş-şeriati'l-âlî, hülâsa-i nev'-i insani'l-müstaîn [El-müsteğnî] zâtuhu ane't-tavsîf ve'l-beyân, el-muhtass bil-lutfi'l-Cell min hazret-i meliki'ddeyyân, padişah-1 sââdet-destgâh, zıllu'l-Lâh-1 ma'delet-nigâh, muînü'd-dîni'lmübîn, nizâmü'l-ümem Alâuddin Şah ca'ale sirrehu evtâd-ı devletihî râsıha ve atvâr-i izzetihî sâmiye-i şâmiha teslimât-1 vâfiyât-1 gevher-nisâr ve tehiyyât-1 sâmiyât-1 mahabbet-şiâr ki mahz-1 inâyât-1 aliyye ve fart-1 himâyât-1 seniyyeden fâyiz münbais olur kavâfil-i tehâyâ ve merâhil-i senâyâ ile huzur-1 mevfûru'l-hubûrlarma iblâğ ve ihdâ kılınur zamîr-i münîrlerine nazîr ve hatır-1 âtır-1 müşteri-te'sîrlerine inhâ ve ifhâm olunur ki hâliyâ atabe-i aliyye-i saadet-medâr ve südde-i seniyye-i gerdûn-iktidarımız ki melâz-ı selâtîn-1 kâmkâr ve melce'-i havâkîn-i âli-mikdardır nâme-i şerifiniz vârid olup küdvetü'l-halâs [havâs] ve'l-mukarribîn veziriniz olan Hüseyin dâme mecduhu vasıtası ile nâme-i şerifiniz vârid olup mazmûn-ı hikmet-makrununda leyl u nihar ol canibde olan küffâr-ı hâksâr ile gazâ ve kâr-zâr olub duşman arasında kâr zâr olup düşman arasında yalnız kalıp her tarafından a'da-yı bed-rây hücûm üzeredir deyû âlât-ı cihâd ile asâkir-i nusrat-mu'tâdımızdan harb-u kitâl ve ceng u cidâl görmüş kullarımız taleb ve istiânet olunup ve ol diyarda yirmi dört bin cezire olup padışahlarının üzerine hayli kâfir gelüb ittifak hezimet vâki' olup ol cezireleri kâfir alıp içinde olan cümle müslümanlar dahi küffâra giriftâr ve padışahları elân memalik-i mahrusanızda [mızda] karar üzere olup ve zikr olunan cezirelerin dördünden Mekke-i Mükerremeye sefer eden tüccar ve hüccac gemileri ol geçide vardıklarında kimini fursat bulup esir edip fursat bulamadıklarını ırakdan top ile urup gemilerin batırıp Müslümanları deryâya gark ederler ve vilayetiniz kurbunda Seylan ve Kalikut demekle ma'rûf iki kâfir padişahı olup raiyyetlerinin ekseri Müslüman olup daima küffâr ile muhârebeden hâlî olmayıp mukaddemâ südde-i saâdetimiz kullarından Lutfi zîde kadruhunun ol cânibe vusûl bulduğuna muttali' olduklarında atabe-i aliyyemize arz-ı ubudiyyet ve ihlâs ve ahd u misâk edip bu tarafdan donanmay-ı hümâyûnumuz varacak olursa kenduları ve kâfir reâyâları eümle imâna gelip b'inâyeti'l-meliki'l-cevâd niyyet-i gazâ ve cihâd ve feth-i vilâyet ve bilâd edeceklerini' i'lâm edip ve Bacıleşka ve Şâika ve Havaî toplardan hisar dövmek için taleb olunup ve elçiniz hususunda ve at ve yarak ve nuhas alındıkda ol diyara varmağa mâni’ olmamak için M1- 
sir ve Yemen Beylerbeyilerine ve Cidde ve Aden Beylerine emr-i şerifimiz gönderilmesini ve hisar ve kadırga bennâlarmdan taleb olunup ve bunlardan gayrı her ne dahi takrir ve tahrir olunmuş ise pâye-i serîr-i saâdet-mesîr-i hüsrevânemize arz olunup ilm-i şerif-i âlem-şümûl-i hidivânemiz muhît ve şâmil olmuştur. Öyle olsa havâkîn-i izâm ve selâtîn-i âlî-makamm iltimas ve istidaları heyyiz-i kabulde vâki' olmak âdet-i hasene-i şahân-ı evreng-nişîn ve kaide-i müstahsene-i padişahân-1 adâlet-âyîn olduğundan ma'dâ hıfz ve himâyet-i din-i mübîn ve zabt u sıyânet'i şer'-i hazret-i Seyyidü'l-mürselîn aleyhi efdalu's-salavât vesselâm babında vâki' olan hususâtın tedarik ve ikmali emrinde sarf-1 makdûr ve bezl-i menşûr etmek ehemm-i vâcibât ve etemm-i ma'rızâtdan olmağın memâlik-i mahrûsamızdan Mısr-1 Kahire tevâbiinden bender-i Süveyș'den onbeș pare kadırga ve iki pare barça dergâh-1 muallâm topcularından topcubaşı ile yedi nefer topcu ve Mısır kullarından kifâyet mikdarı asker-i nusret-eser t'ayin olunup ve kal'alar için kifayet mikdarı top ve tüfenk ve sâir edevât-ı harb ve ceng verilmek emrim olup ve ta'yin ve irsâl olunacak asâkir-i fevz-meâsire sâbıka İskenderiye Kapudan olup Sancağa mutasarrif olan iftiharü-l-ümerâi'l-kirâm muhtarü'l-küberâi'lfihâm zevi'l-kadr ve'l-ihtirâm el-muhtass bi-mezîdi inâyeti'l-meliki'l-allâm Kurd oğlu Hızır dâme uluvvuhu serdâr ta'yin olunup inâyet-i Hakk-1 cell u alâya tevekkül-i tâm ve mu'cizât-ı kesîrü'l-berekât hazret-i seyyidü'l-ebrâr aleyhi's-salavâta tevessül-i mâlâ-kelâm kılınıp küffâr-ı hâksâr-1 duzah-karâr ile cihâd-1 fî-sebili'l-Lah için savb-1 savâb-nümâya irsâl olunup müşârünileyhe şöyle emrim olmuştur ki inşallahu Taâla size varıp mülâki oldukda eğer feth u teshiri lâzım olan kal'alardır ve eger sâir küffâr-ı hâksârın haklarından gelmektir siz vech ve münasip gördüğünüz üzere din bâbında ve devlet-i hümâyûnumuza müteallik olan umûrdan bezl-i makdûr eyleyub eger müşârünileyh ve eger sâir koşulan topcu ve asker halkının sağîr ve kebîri aslâ size muhâlefet etmeyip her ne yüzden vech ve münasip görürseniz tâbi’ olup hidmetde olalar. Anın gibi muhâlefet edenlerin müşârünileyh ma'rifeti ile haklarından gelesiz ve irsâl olunan askerin bir yıllık mevacibleri verilmiştir. Gerektir ki siz dahi din babında ve devlet-i hümâyunumuza müteallik olan umûrda bezl-i makdûr eyleyip küffâr-ı hâksârın eğer kal'aların feth etmekte eger ehl-i islâm üzerlerinden şerr u sevrlerini def' etmekte sa'y u ikdâm eyleyip inâyet-i hak celle ve alâ ile ol diyarı televvüsât-ı küfrden tathîr ve pâk eyleyesiz ki eyyâm-1 ma'delet-encâm -1 hüsrevânemizde ol diyarm ehl-i islâmı dahi âsûde-hâl olup ferâğ-ı bâl ile kâr u kisblerine meşgul olalar. Ínşallah murâd üzere eger kal'a ahvâli eger memleket hıfzı görülüp zimâm-ı maslâhat oldukda irsâl olunan topculara icâzet veresiz ve sâir ahvâl ve etvâr 
her neye müncer olursa müşârünileyh Mustafa Çavuş ile i'lâm eyleyesiz. Sonra anda olan asker hakkında ferman-ı şerifim ne vechile sâdır olursa mûcibi ile amel eyleyesiz ve nâme-i şerifiniz vürûdu esnasında takdir-i hazret-i mukadderü'l-âmâl ile azze şânehu cenab-ı mağferet-penâh ve rahmet-nisâb merhum ve mağfurun leh babamız Sultan Süleyman Şah-1 kuds-âşiyân enârellahu burhânehu asâkir-i mansûre-i müslimîn ve leşker-i deryâ-şlâr-1 muvahhidîn ile küffâr-i hâksâr-ı hezimet-âsâr ile cihâd-1 fî-sebilillah içün gazay-1 garrây-ı nusrat-intimâya azîmet etmişlerdi, hudud-i nâ-ma'dûd-ı frengistandan küdve-i erbâb-ı dalâl olan ikbâl-i frengden Nemçe Kıralı olan mel'ûn-ı dalâletmakrûnun a'zam-ı husûn-ı metânet-makrûnundan kal'a-i mansûre-i Sigetvar'ın fethine azîmet etmişlerdi. Bi-inâyetillahi'l-müheymeni'l-fettâh leşker-i islâm-i nusrat-peyâm ile ol hısn-ı hasîni feth eyleyip memâlik-i vasîa-i frengistandan bî-nihâye memleketler ve kal'alar alındıktan sonra vücud-i mevdûd-i şehâdet-vürudları dâr-ı fenâdan âlem-i bekâya irtihal eylediler الحلكملَّ والواحد القهار Lâ cerem avn u inâyet-i ilâhî ve savn u sıyânet-i nâ mütenâhî birle serîr-i saâdet ve ikbal-i zât-i aliyyemiz ile müstes'ad olup inşallahu'l-eazzü'l-ekrem hâtır-1 âtır-1 cihan-bânî ve niyyât-1 amîmü'l-berekât-i giti-satanî dâimâ küffâr-1 hâksâr ile cihâd ve gazadan halî olmamak üzere mukavvîdir. Çünkü ol câniblerden dahi kefere-i fecerenin خذلكة الله تعالى ahvâl-i dalâlet-meâlleri nâme-i dürer-bârınızda şerh ve tafsîl olunduğu üzere Açi'ye beher hâl ihvân-1 sadâkat-nişâne merâsim-i muâvenet u meded-gârî ve levâzim-i muzâheret destyârîde âsâr-1 ikdâm ve ihtimâm mebzûl ve mecbûl kılınur. Hak subhanehu ve taâlânın izz u cell âsitâne-i ikbâl-âşiyânemiz kıbeline vufûr-i imdâd-1 aliyyeleri derece-i tafsîl u şumârdan mütecâvizdir. İnşallahu'l-eazzü'l-ekrem ol câniblerde dahi memâlik-i islâmiyyeye dahi müstevlî olan a'dây-1 din-i mübîn ve düşmenân-1 âyîn-i seyyidü' l-mürselîn aleyhi's-salâtu ve's-selâmun def'-i mazarrat ve dalâletleri içün asâkir-i cerrâr-1 nusrat-şiârımızdan daimâ ol cânibe irsâl olunur. Bu zamanda kaide-i müstemirreniz üzerine me'mûldur ki ol diyarm ahvâl ve macerası mufassal meşrûh atebe-i âlem-penâhımız cânibine inbâ olunmakdan hâli olunmaya ve müşârünileyh veziriniż gönderilmek içün bahâr[m] ihzâr olunmuş idi. Barçalar irsâl olundu, tahmîl olunup gönderile ve gelen elçiniz dahi şol ki şerâyit-i resâletdir kemâl-i âdâb ile edâ edip hüsn-i icâzetimize mukarin olup irsâl olunmuştur. 


\section{SULTAN II. SELIM TARAFINDAN, AÇİ PADİŞAHINA YARDIM GÖTÜRMESİ İÇIN KURD OĞLU HIZIR REİS'E VERİLEN NIŞAN-I HÜMÂYÛN.}

Mühimme Defteri No. 7, s. 86, sura No. 233

Elçi ile bile irsâl olunan mezbûr Mustafa Çavuşa verildi, fî 17 Rebiulevvel 975.

Nişan-ı Hümâyûn hükmü oldur ki hâliyâ Açi Padişahı olan cenâb-ı emâret-meâb Sultan Alâuddin dâmet maâlihi âsitâne-i saadetime mektup ve adam gönderip ol cevânibde ba'zı ehl-i islâm üzerine Portakal keferesi müstevlî olup ve kendu vilayetine dahi dahl ve tecâvüz üzere olup ol cevânibde olan ehl-i islâmın muâveneti için atabe-i ulyâmdan bir mikdar gemiler ve yarak ve asker rica etmeğin salâtîn-i âli-mikdarın istid'a ve iltimasları hîz-i kabulde vâki' olmak âdet-i hasene-i havâkîn-i evreng-nişîn olmağın ol cevânibde olan ehl-i islâmın hususlarında mezîd merhamet-i hüsrevânem zuhûra gelip küffâr-1 hâksârın def'u ref'leri için bender-i Süveyş'den onbeş pâre kadırga ile iki pâre barça ve sâir levâzımı vermek emr edip zikr olunan gemilere ve asâkir-i zafer-rehbere bir serdâr-1 âli-mikdar-1 azîmü'l-iktidâr lâzım olup öyle olsa bundan akdam mahrusa-i Misr İskenderiyye'sinde sancakları ile kapudanı olan iftiharü'l-ümerâi'l-kirâm Kurd oğlu Hızır dâme izzehunun vufûr-i ferâset ve kiyâset ve fart-1 şecâat ve şahâmet[ine] i'timad-1 hümâyûnum olmağın irsâl olunacak merâkib-i kevâkib-şumâr ve asâkir-i nusrat-şiâra mumâileyhi serdar ve kapudan nasb edip bu nişan-1 hümâyûn-1 saâdet-makrûnu verdim ve buyurdum ki fermân-ı celîlü'l-kadrım üzere ta'yin olunan gemiler ve asker ile müşârun ileyh taraflarma teveccüh eyleyip inâyet-i Hak celle ve alâ ile inşallah varub müşârünileyhe mülâkı olunca eger gemileri eger askeri hüsn-i tedârik ile hıfz eyleyub varub mumâileyhe vüsûl buldukda eger küffâr-ı hâksârın def' ve ref'inde eger teshiri lâzım olan kal'aların istihlâsında müşarünileyh Açi Padişahı vech ve münâsip gördüğü üzere hizmet ve yoldaşlıkda bulunup müşârünileyhin sözüne muhâlefet etmeye ve bile koşulan eger dergâh-1 muallâm kullarından ve mahrusa-i Mısr kullarından ve sâir asker halkı ve gemi mürettebâtları ve sâir halkı ve bilcümle asâkir-i mansûrenin vazî’u refîi ve sağîr u kebîri müşârünileyhi kendulara serdar bilub sözüne aslâ muhâlefet ve emrine muânedet etmekten hazer eyleyeler. Her kim inad ve muhâlefet ederler ise mecâl vermeyip hakkından gele ki sâirlerine mucib-i ibret vâki' ola. 
Açi padişahının diğer rıcaları yerine getirilmek için ve hiç bir güçlük çıarılmaması hakkında Yemen ve Mısır Beylerbeyilerine, Rodos, Cidde ve Aden Beylerine ve Mekke Şerifine gönderilen hükümlerin metinleri:

Mühimme Defteri No. 7. s. 89, sura No. 237

Yemen Beylerbeyine hüküm ki cenâb-ı emâret-meâb Açi padişahı tarafindan südde-i saadetime elçi gelip geru ol canibe gönderilmiştir. Mumaileyh elçi at ve yarak ve nuhas alıp gitmelu oldukta kimesne mâni' olmamak için emr-i şerifimi talep eylediği ecilden buyurdum ki müşarunileyhin elçileri varup vusul buldukta müşarunileyh için at ve yarak ve nuhas aldıklarmda mâni' olmayıp ve alınan esbaplarına nevllerden kimesneye hazer ettirmiyesin, emin ve sâlim mürurlarında ve bilcümle eger berudan gittiklerinde eger andan geldiklerinde hilaf-ı şer' ve kanun kenduya ve esbab ve adamlarma dahl ettirmiyesin; her ahvallerinde muâvenet edesin.

$\begin{array}{lc}\text { Bir sureti Cidde Beyine } & \text { Bir sureti Aden } \\ \text { vech-i meşru' üzere } & \text { Beyine }\end{array}$

Mühimme Defteri No. 7, s. 89, Srra No. 238

Mısır Beylerbeyine hüküm ki Açi padişahı tarafından südde-i sââdetime gelen elçileri mumâileyh tarafından bazı kimesneler talep edip evvel dülger ve demirci ve kalkancı ve nakkâş ve gayrı sanat ehlinden talep ettikleri kimesneler defter olunup sana gönderilmiştir. Buyurdum ki vusul buldukta ol defterde mastûr olan ehl-i sanayi'dan eger ulufe tasarruf edenlerdir ve eger ulufesizlerdir ta'yin olunanları zikr olunan elçilere koşup bile gönderesin.

Mühimme Defteri No. 7, s. 89, Sıra No. 239

Mısır Beylerbeyine hüküm ki hâliyâ Açi padişahı tarafına irsâl olunan kadırga ile Mısır kullarmdan her kim ki irâdetiyle gitmek isteyenlere icâzet vermek emredip buyurdum ki anun gibi gitmek isteyenlere mâni' olmayıp muraả edenlere icâzet verip gönderesin ve gidenler ihtiyarlari ile evlerine birer miktar harchk verirlerse mânı' olmayasın. 
Rodos Beyine hüküm ki hâlâ südde-i saâdetime gelen Açi padişahı elçisine hüsn-i icâzetime mukârin olup kadırga ile Mısır camıbine irsâl olunmuştur. Buyurdum ki ferman-ı şerifim ile müşârunileyh elçi sana varıp vusul buldukta eğlendirmeyip bizzat alı yanında olan kadırgalar ile emin ve sâlim Mısır'a ulaştırasın ve Mısır'a varıp dahil olduktan sonra binip gittiği kadırgayı alıp atebe-i ulyama gönderesin.

Mühimme Defteri No. 7, s. 90, Sira No. 242

Bu dahi elçi ile bile

giden Mustafa çavuşa verildi.

Mekke-i mükerreme Şerifine hüküm ki hâliyâ Açi padişahının südde-i saâdetime gelen adamları geri icazet-i şerifimle ol canibe gönderilmiştir ve kılavuz lazım oldukta vermek babında hükmü-i hümayunum talep etmeğin gerektir ki hüküm-i şerifim ile varıp vusul bulduklarında anun gibi suları ve eger zahireleri ve kılavuz babında gereği gibi muâvenet ve muzaheret olunup emin ve salim irsâl etmek envâ'-i mesâî-i cemile zuhur ide ve müşârunileyh için at aldıklarında dahi kimesne mânı' olmaya.

\section{Mühimme Defteri No. 7, s. 90, Srra No. 243}

Mısır Beylerbeyine hüküm ki hâliyâ Açi padişahından gelen elçiye icâzet verilip gönderilmiştir. Buyurdum ki varıp İskenderiye'ye vusul buldukta iskelede vesâir yerde kenduya ve adamlarına ve mahsus esbablarma eminlerden ve gayriden kimesneye dahl ettirmeyesin.

Mühimme Defteri No. 7, s. 177, sura No 474.

Mısır Beylerbeyine hüküm ki hâliyâ südde-i saâdetimden Açi padişahma irsâl olunacak gemilerle bile gönderilen südde-i saâdetimden irsâl olunan reisler gidecek gemiler kendülere verilmek rica idüp buyurdum ki vusul buldukda göresin anun gibi anda olan reislerden gemi kullanmak babında bunlar evlâ olup yararlar ise gönderilen gemilere yarar olanları reis tayin eyleyesin gemi kullanmağa kâdîr ola. 
Mühimme Defteri No. 7, s. 182, sura No. 491.

Kapudana hüküm ki hâlâ emr-i şerifle Açi padişahına gönderilen reisler vesâir nefer hidmetlerini edâ idüp geldiklerinde kemâ kân ulufeleri mukarrar olup verilmesi emr idüp buyurdum ki emrim üzere müşârünileyhe gönderilen reisler ve gayrlar varub kasurları olmayub hidmet ettiklerine mumaileyhten asker götürdüklerinde mütasarrif oldukları ülufelerine tasarruf ettiresin.

YEMEN'DE ÇIKAN ISYAN YÜZÜNDEN, PORTEKIZLILERE KARŞI AÇI PADISSAHINA GÖNDERILECEK DONANMANIN TEHIRİNE DAİR AÇI ELÇISINEE GÖNDERILEN HÜKÜM:

Mühimme Defteri No. 7, s. 255, sma No. 708.

Mustafa çavuşa verildi

22 Recep yazılış tarihi

15 Recep 975 (15-1-1568)

Açi padişahının elçisi Hüseyin'e hüküm ki hâliyâ Yemen canibinde fitne zuhur edip def' ve ref'leri ehemm-i mühimmatdan olmağın vilayet-i Hind'e irsâl olunacak donanma-i hümayun bu sene tehir olunmuştur. Buyurdum ki inşaallah-1 teâlâ inâyet-i hakk Celle ve alâ ile ol canibin fitne ve fesâdı def' ve ref' olduktan sonra zikr olunan donanma-i hümayun muâhede olunduğu üzere müretteb ve mükemmel bî-kusur irsâl ve isâl olunur. 


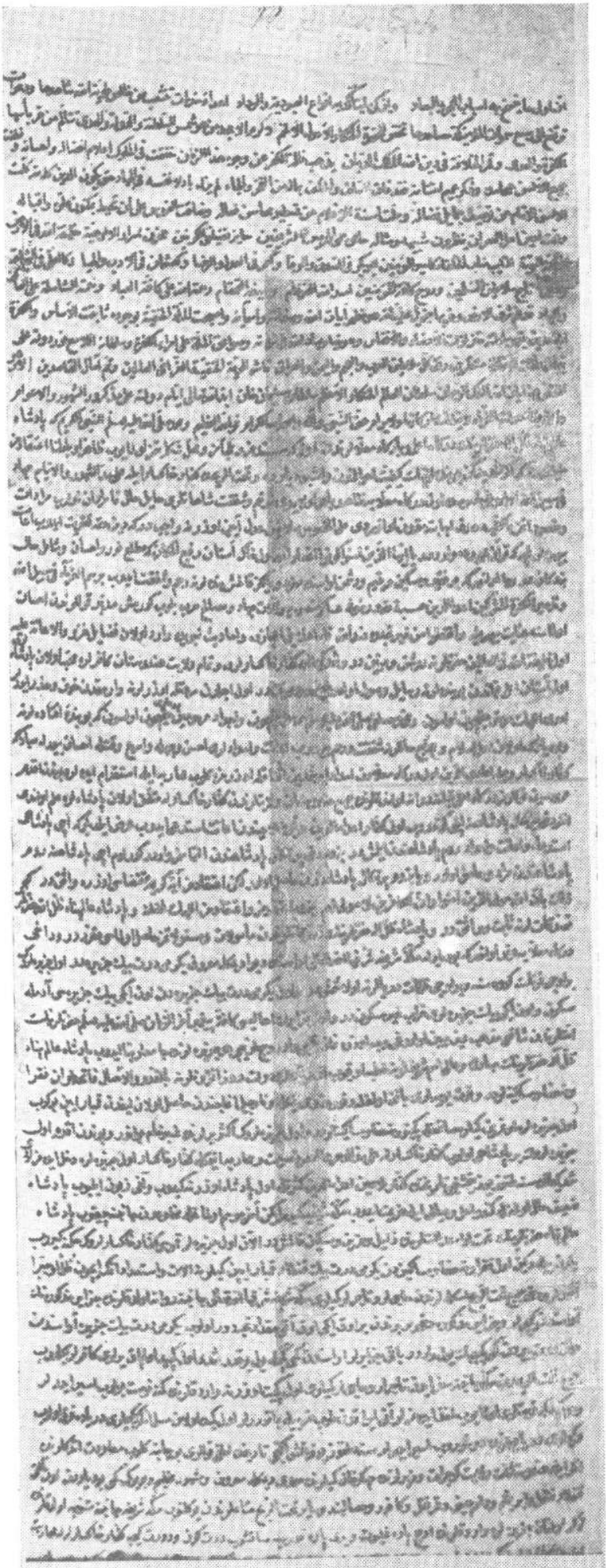

Ek No 1 


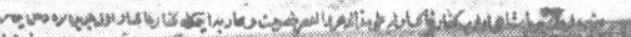

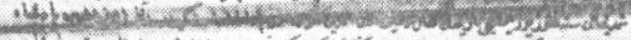

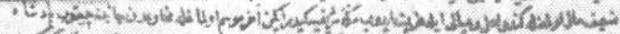

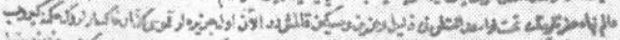

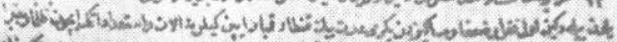

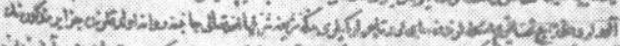

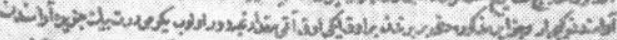

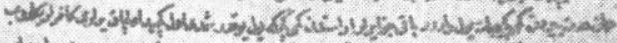

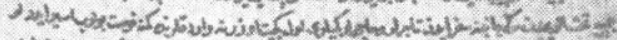

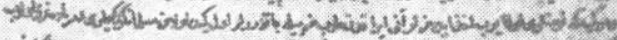

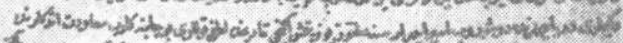
Sy

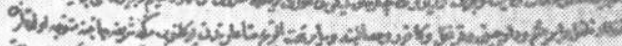

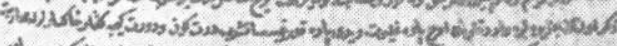

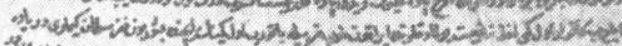

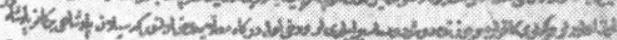

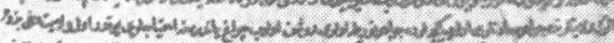

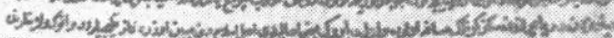

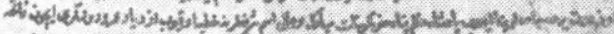

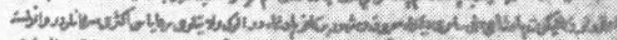

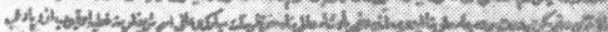

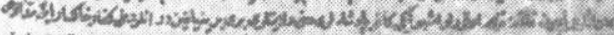

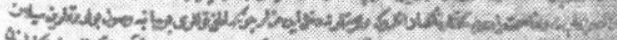

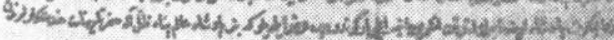

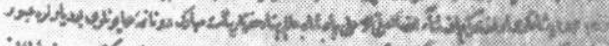

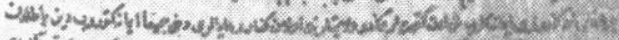

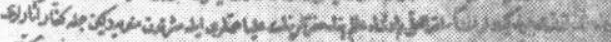

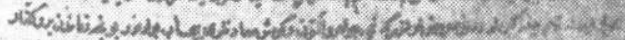

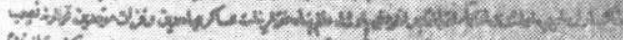

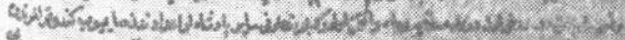
3.4.

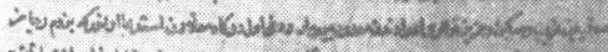

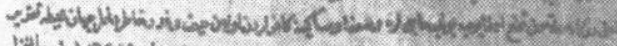

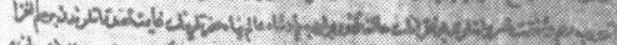

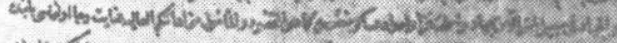

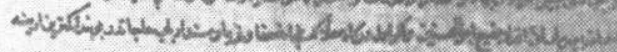

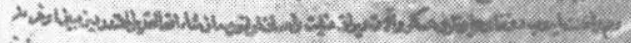

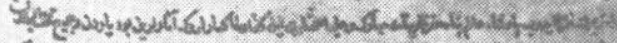

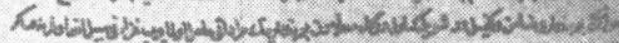

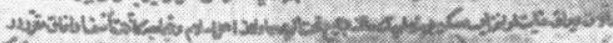

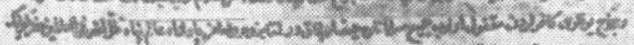

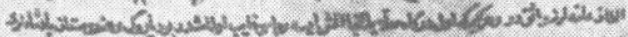

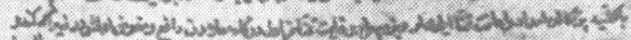
का to

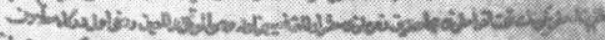

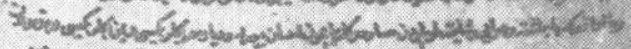

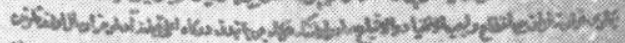

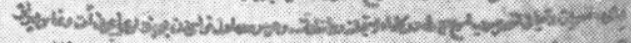

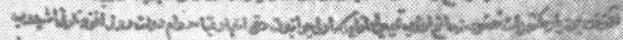

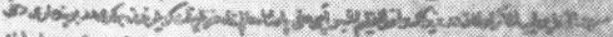

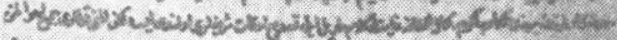

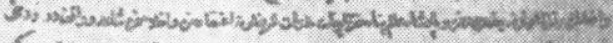

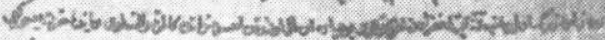

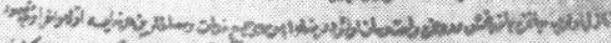

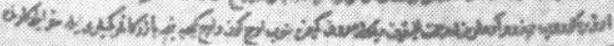

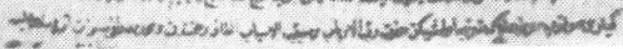




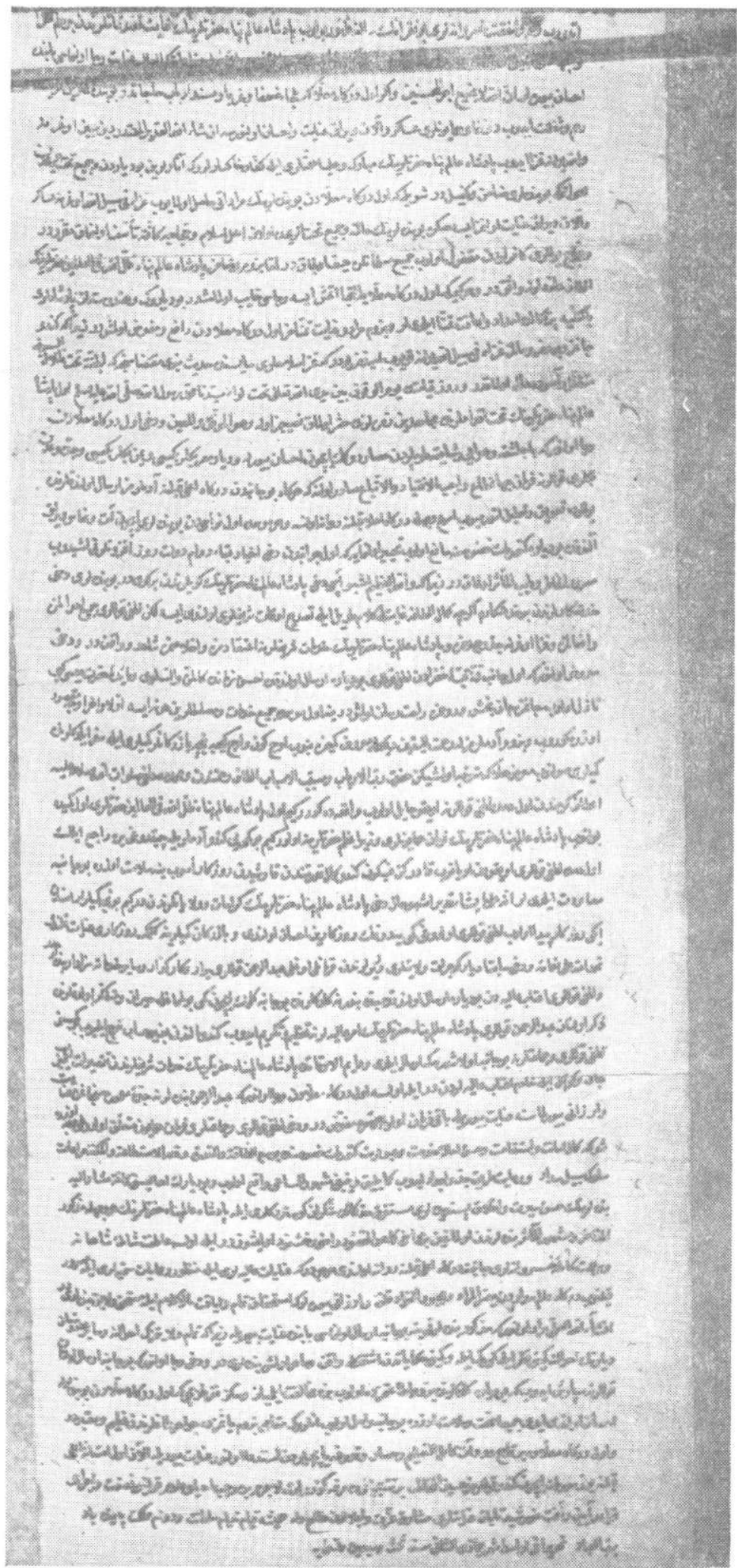

Ek No 3 


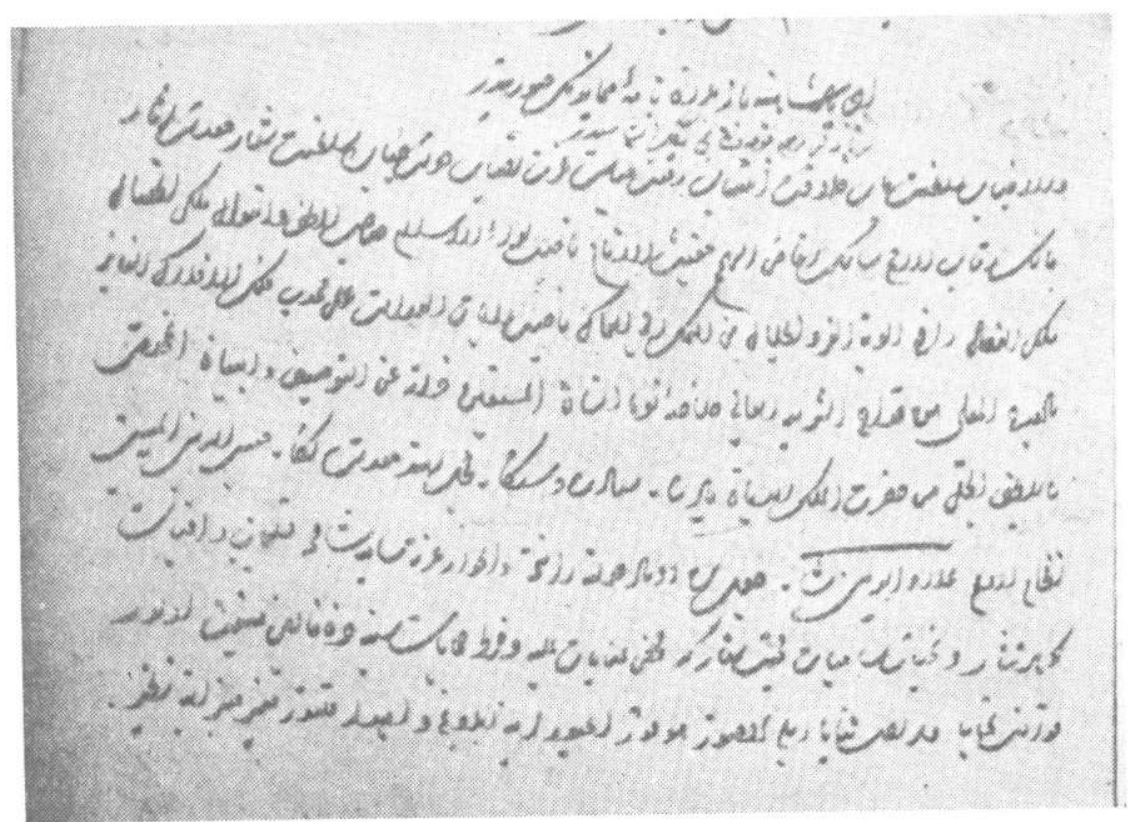

Ek No 4 


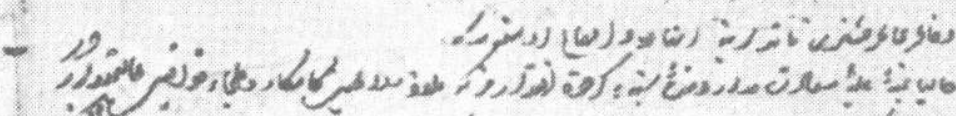

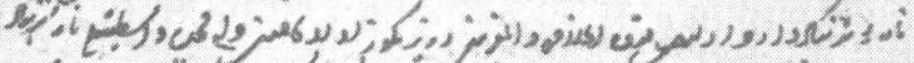

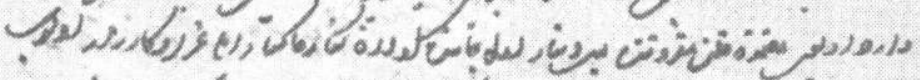

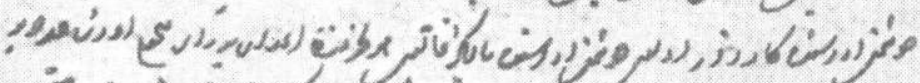

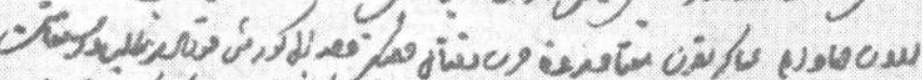
iw so.

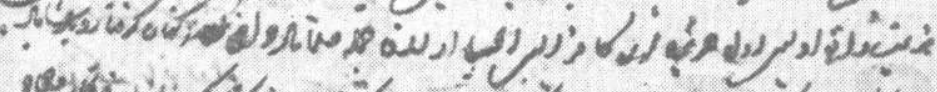

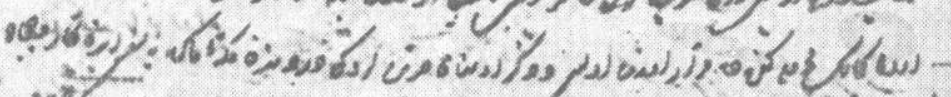

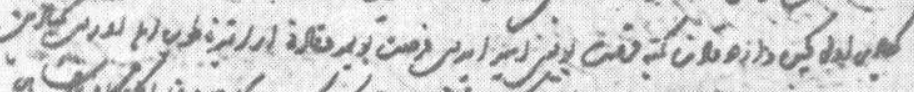

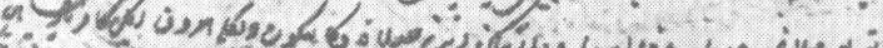

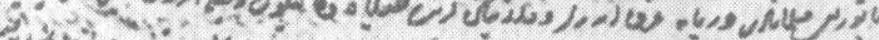
-

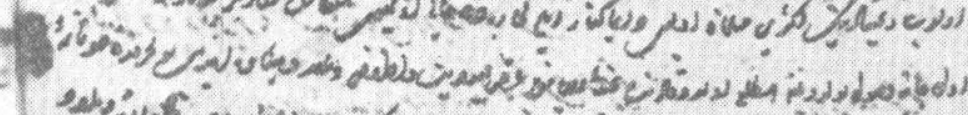

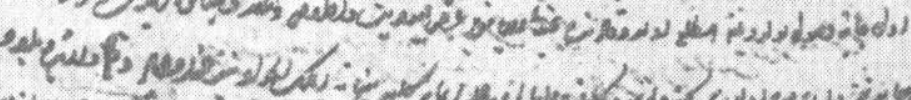
ueir

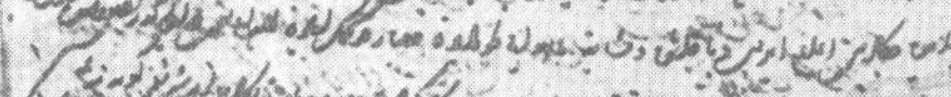

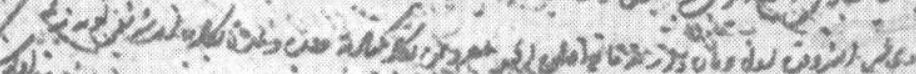

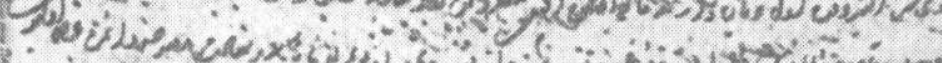
U-р ol 6.

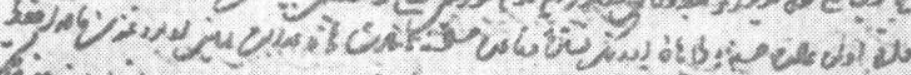

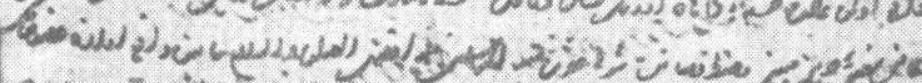
c.

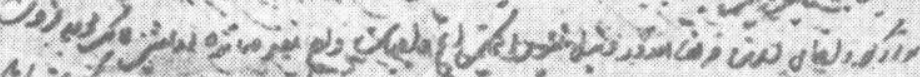

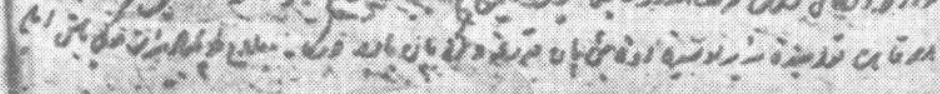

Ek No 5 
AÇi PADIŞAHI SULTAN ALÂEDDIN'iN MEKTUBU

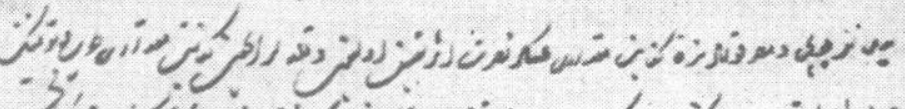

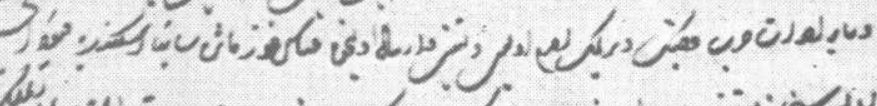
"lu'

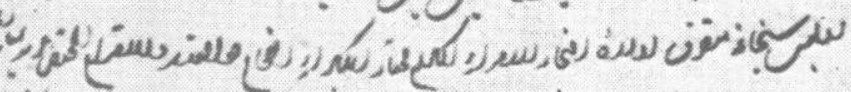

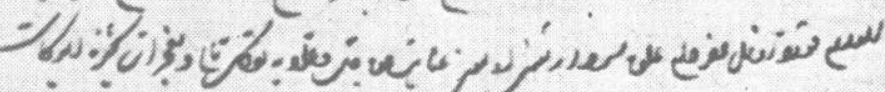

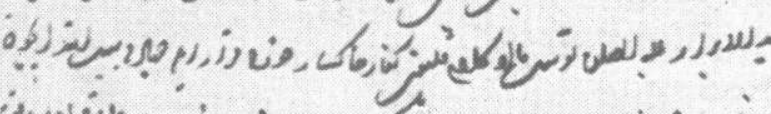

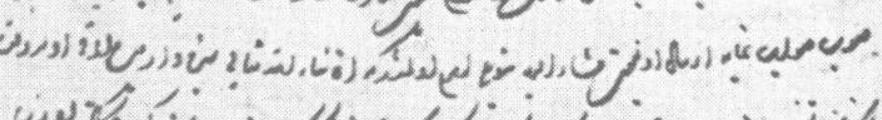

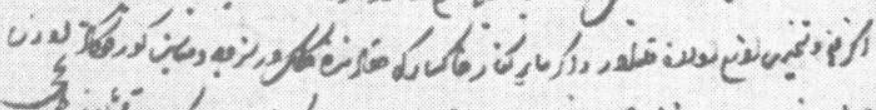

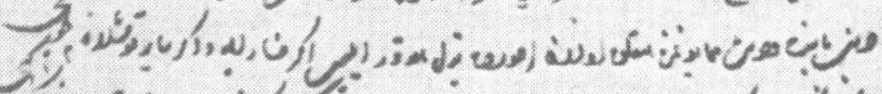

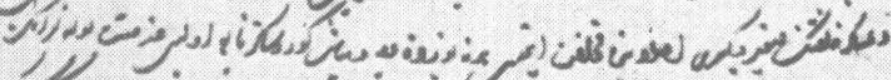

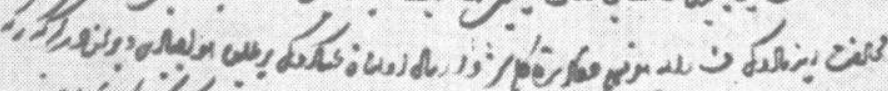

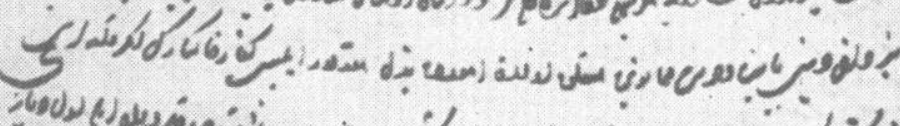
Yo

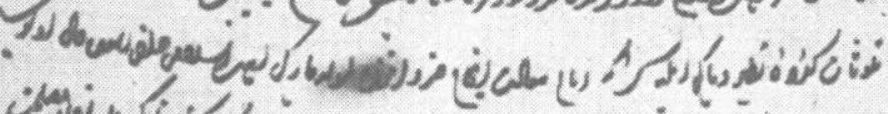

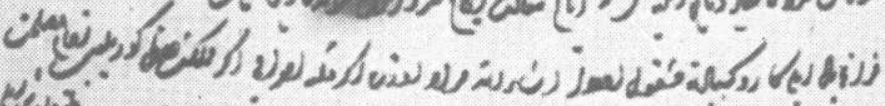

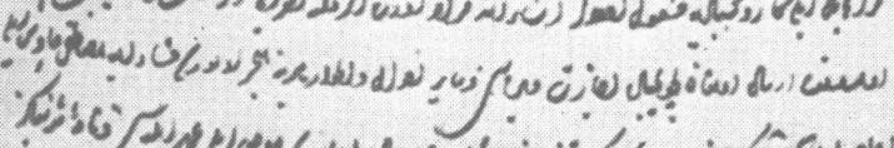

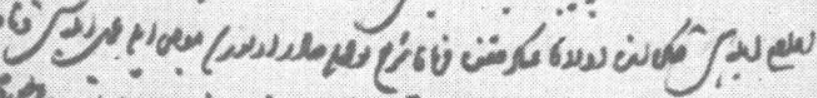

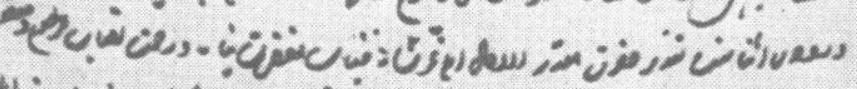

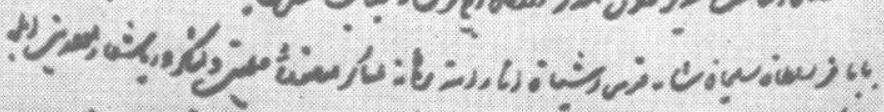

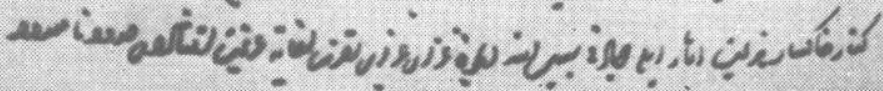

Ek No 6 


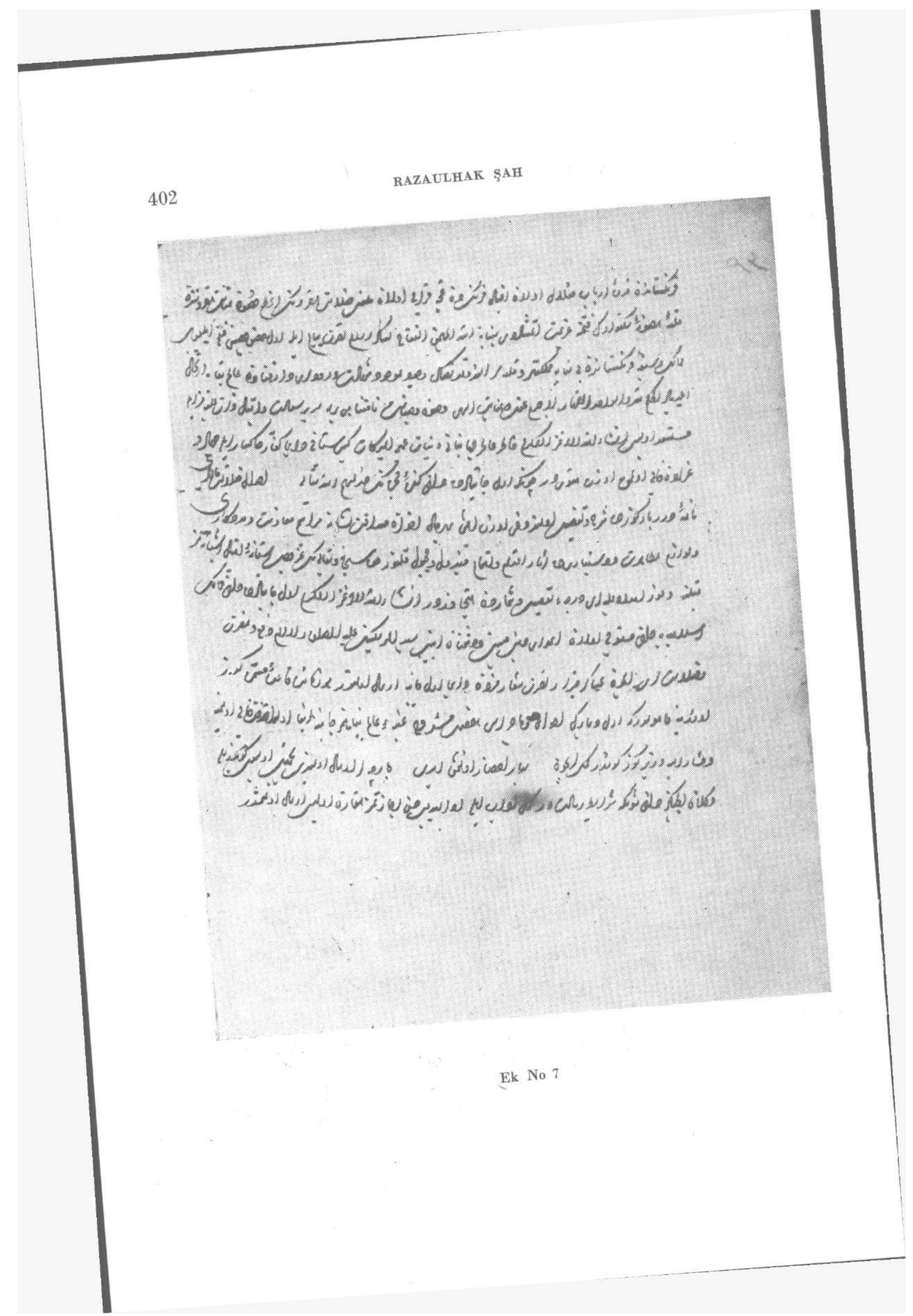


AÇi PADIŞAHI SULTAN ALÂEDDIN'in MEKTUBU

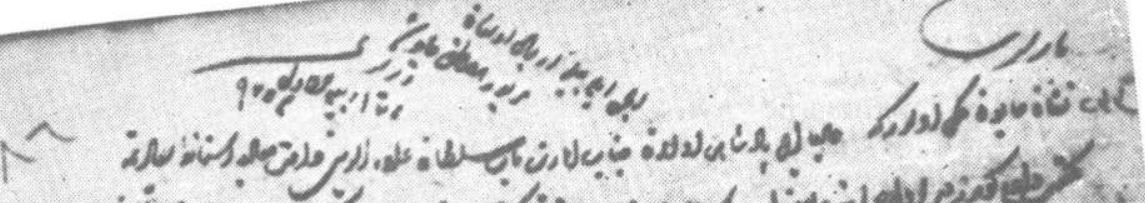

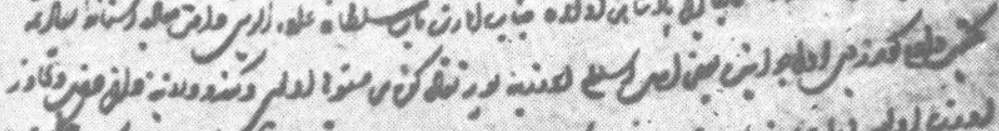
لف

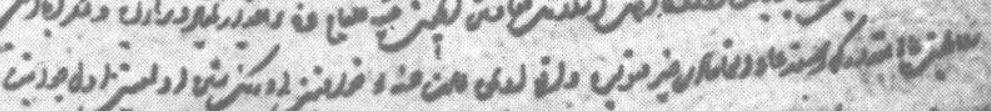
ats

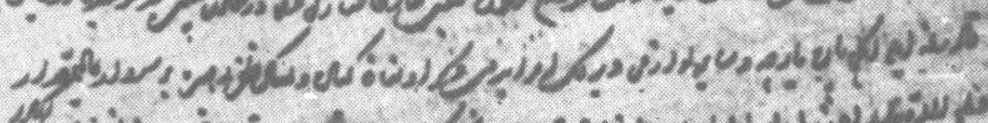

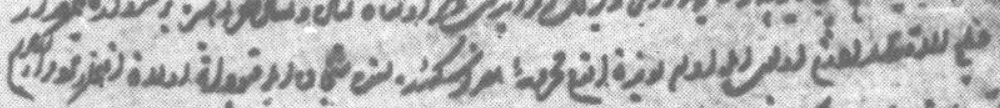

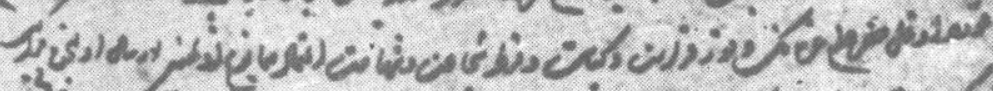

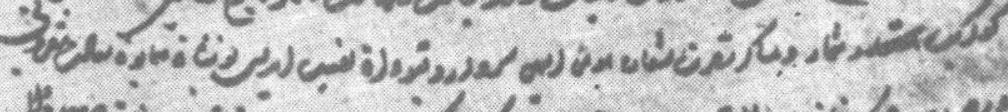

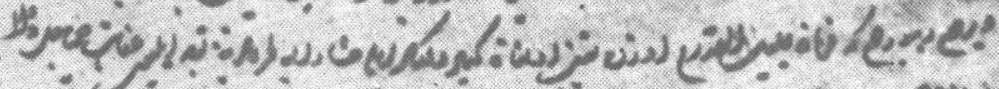

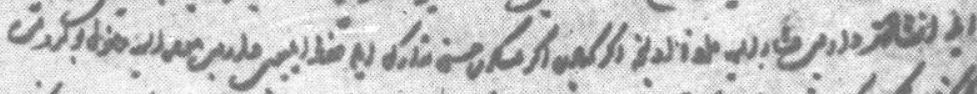

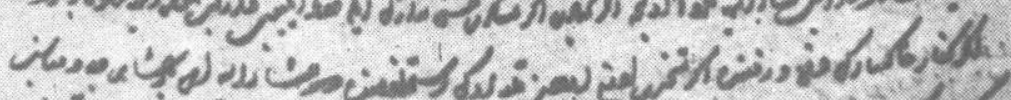

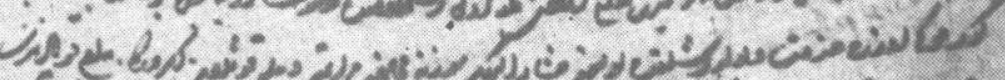

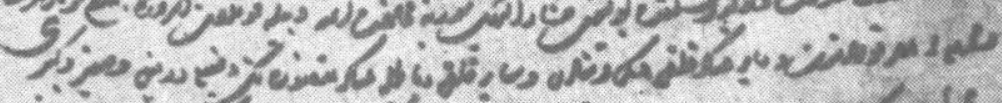

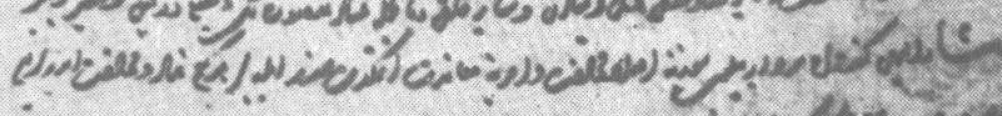

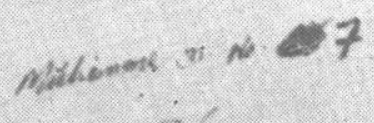
5.4. 86 icosintion -20

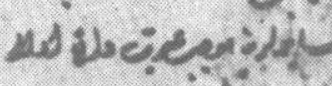

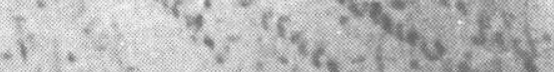

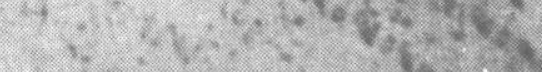




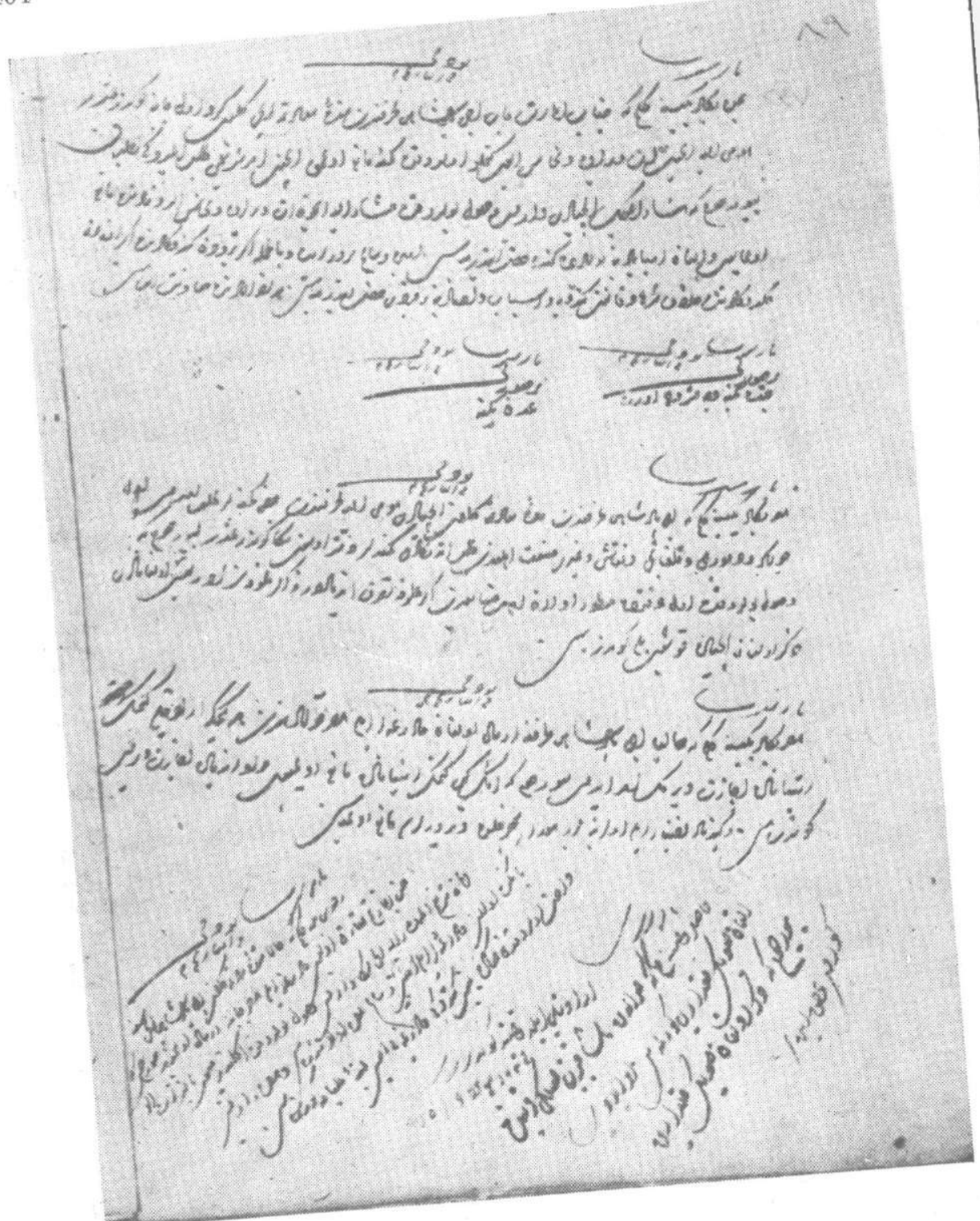

Ek No 9 


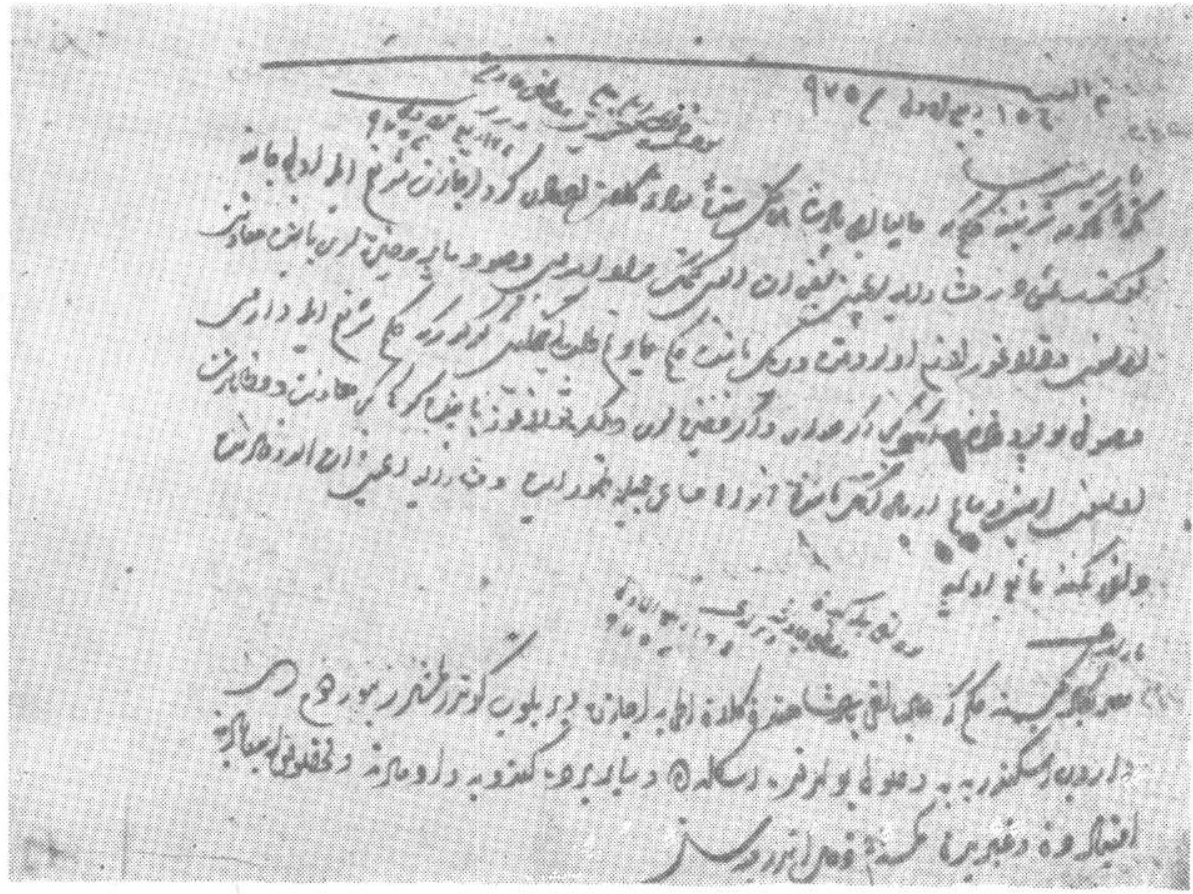

Ek No 10

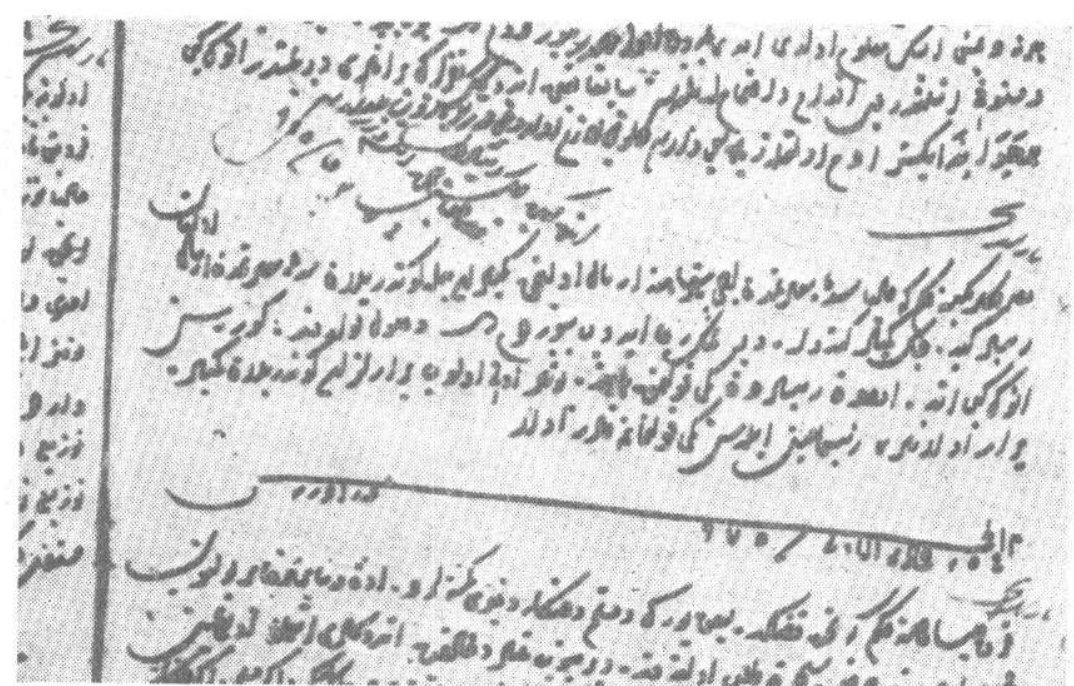
Ek No 11 


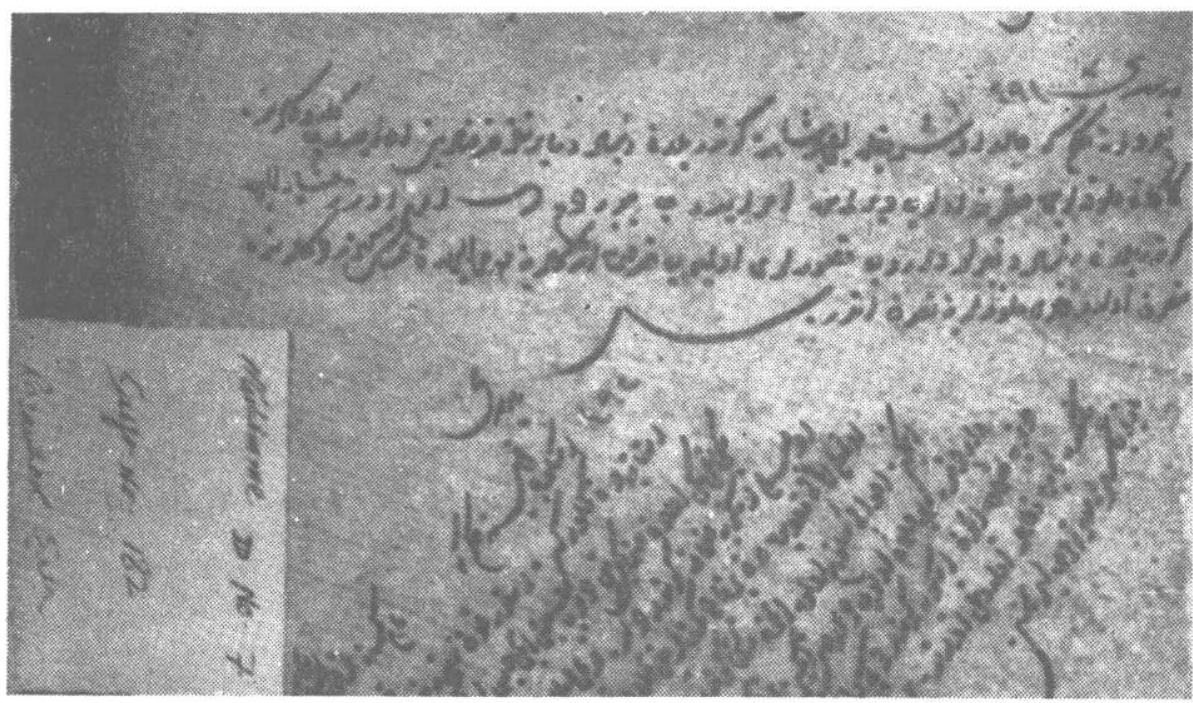

Ek No 12

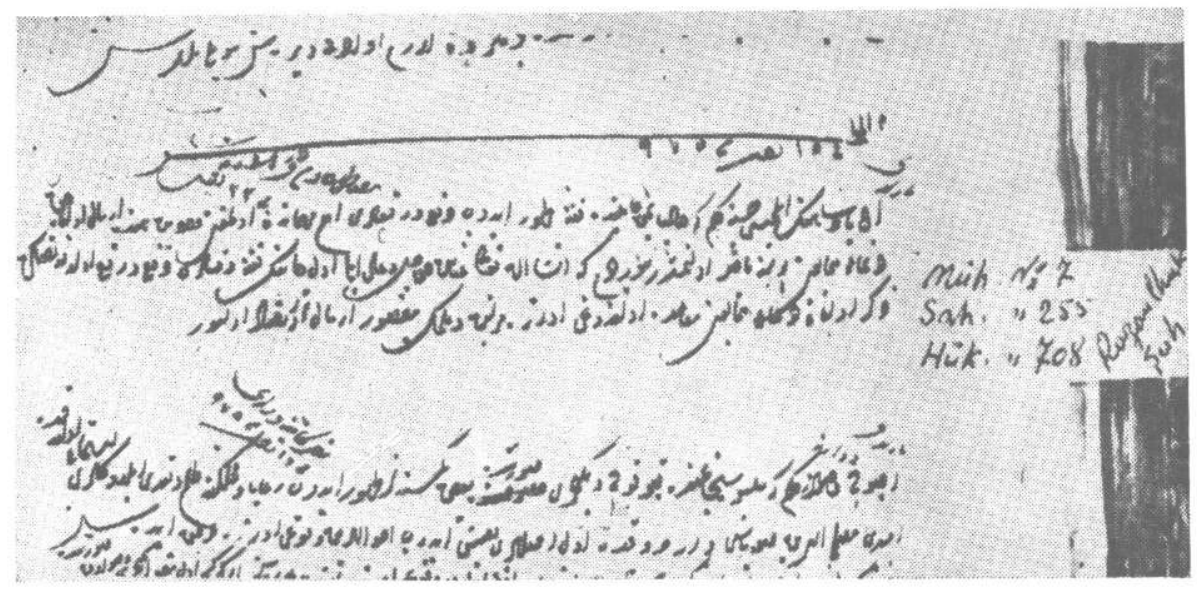

Ek No 13 


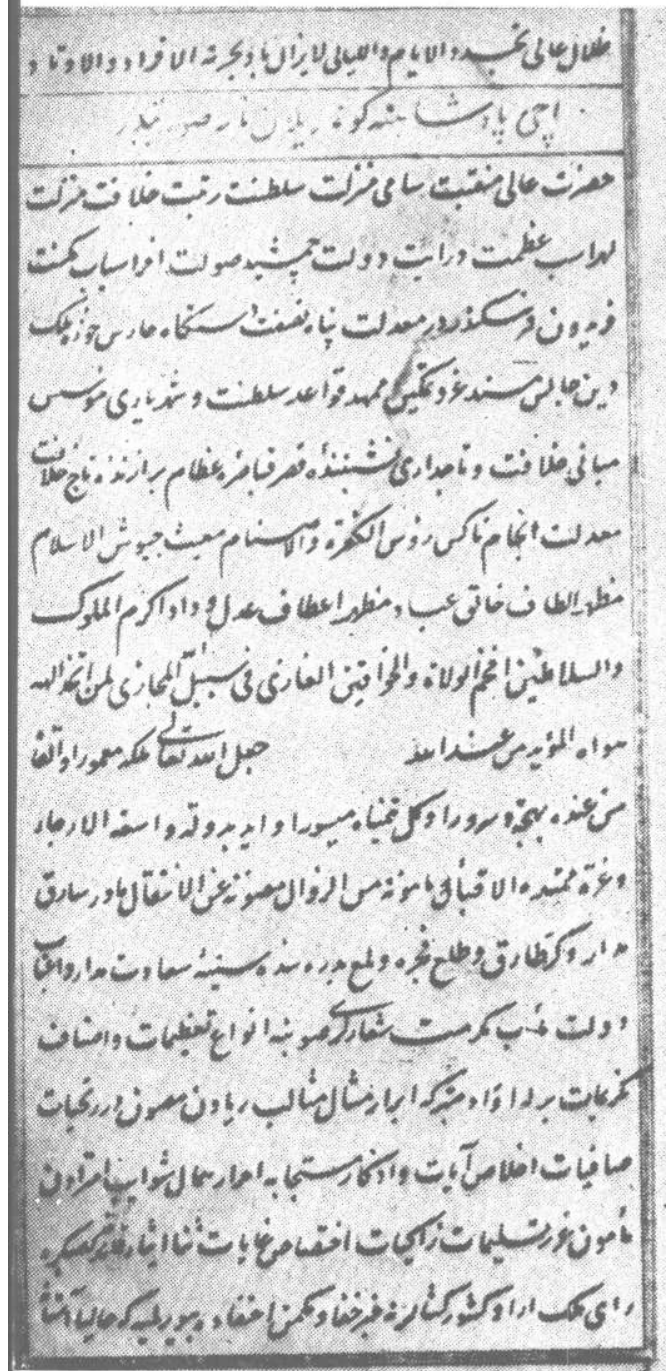

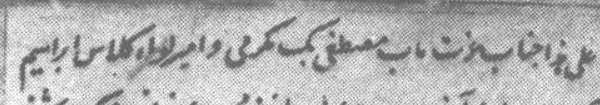

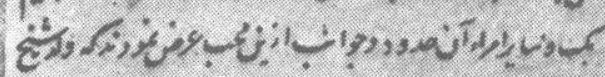

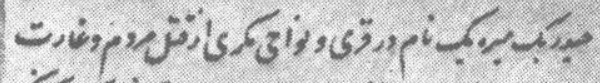

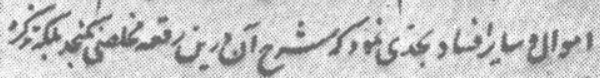

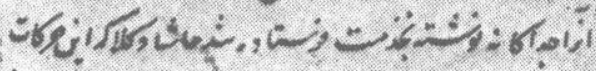

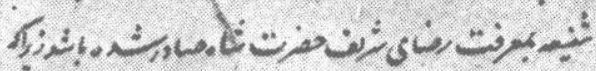

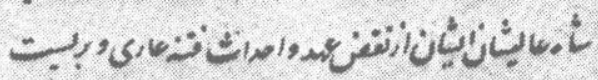

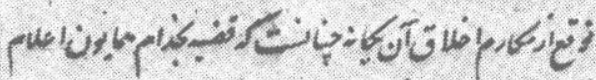
بُ

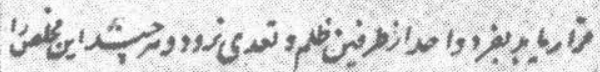
|

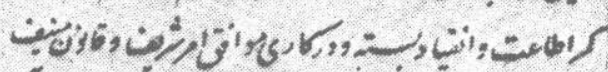

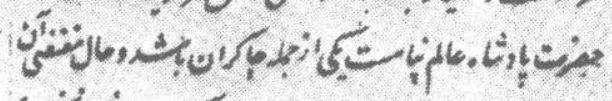

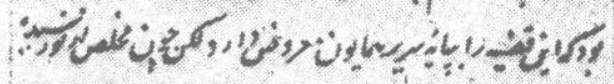

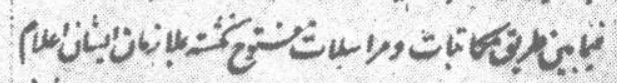

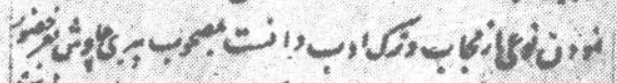

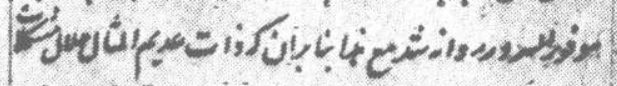

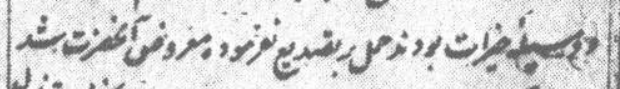

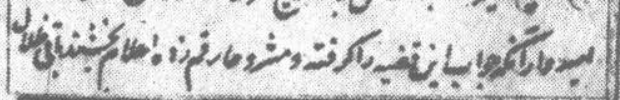




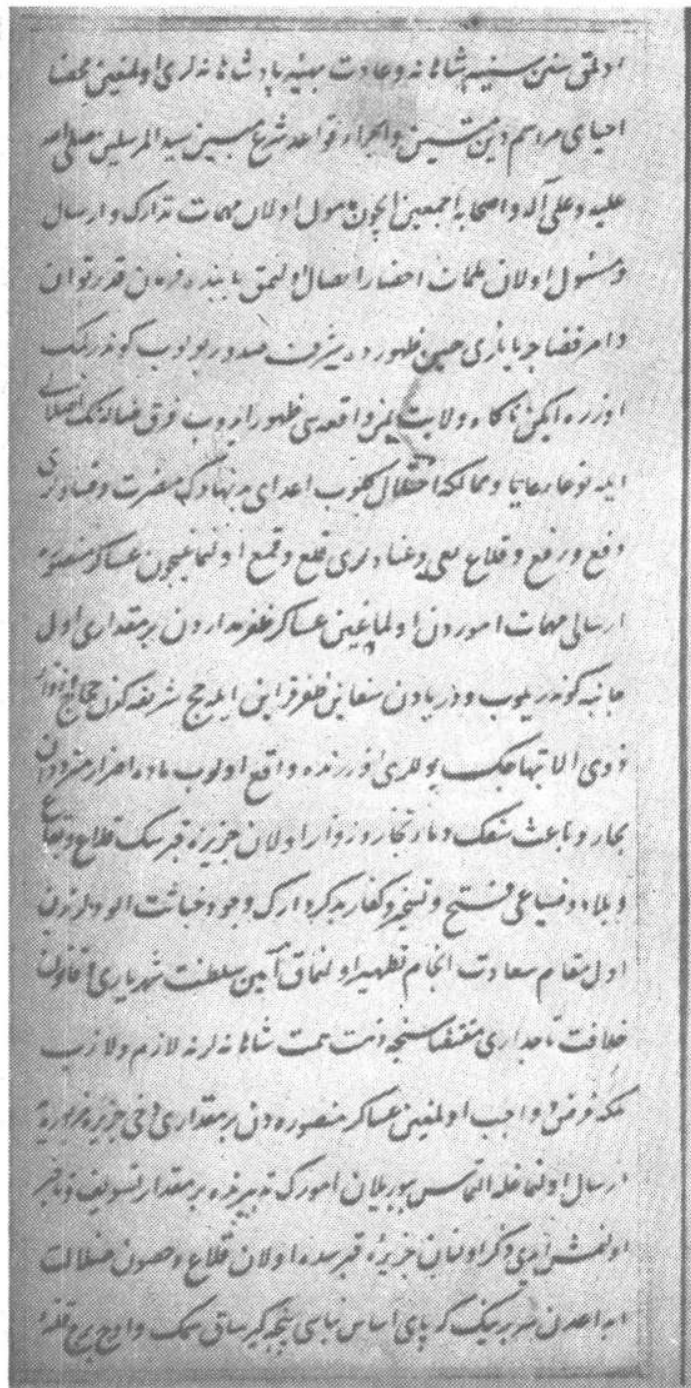

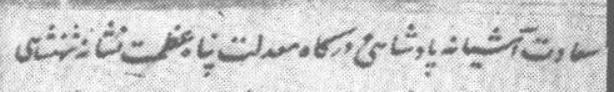
|l كان

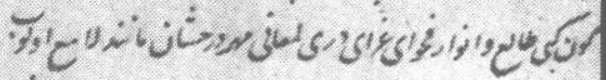

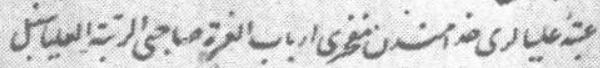
iان أt أis

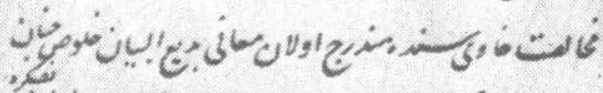

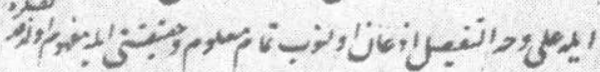

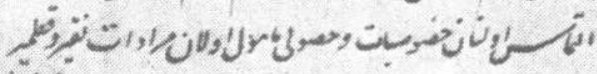

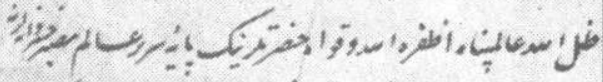

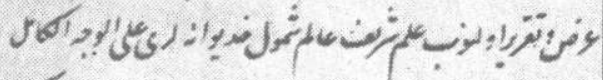

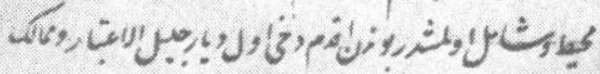

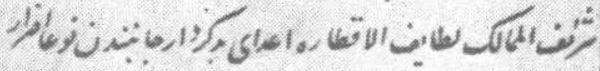

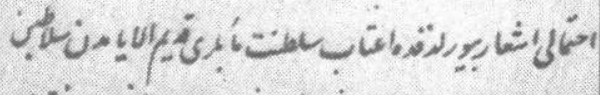

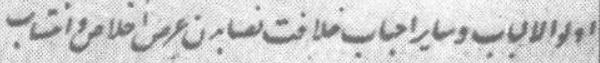

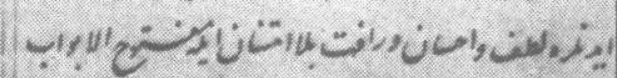

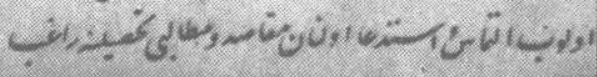




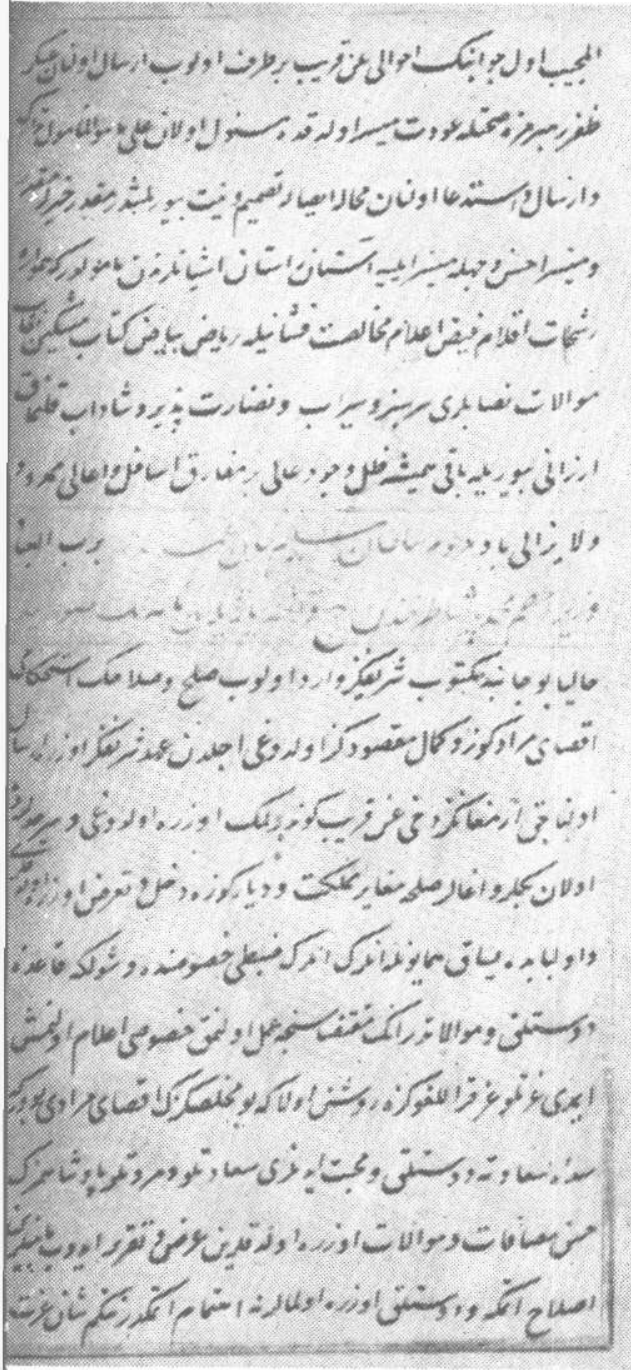

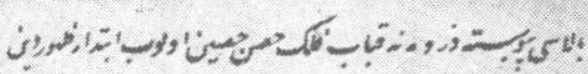

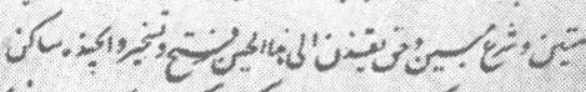

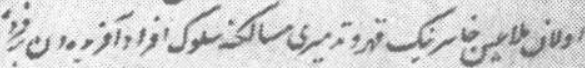

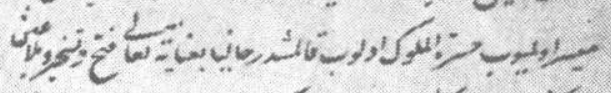

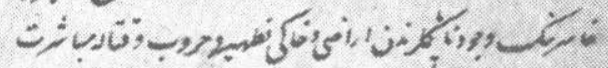

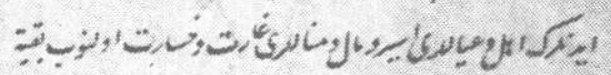
" تهان

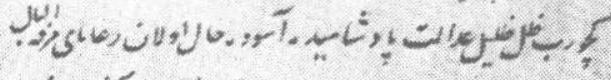
内.

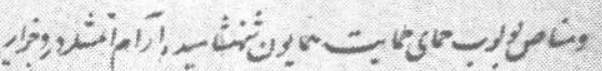

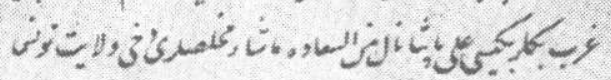

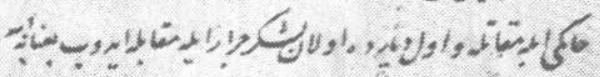

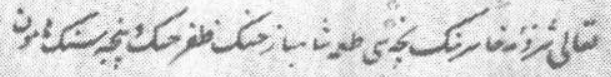

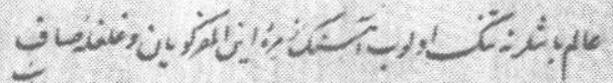
荡

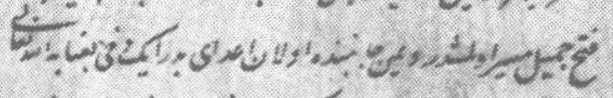
施

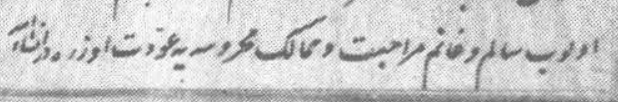

